Revista lus et Praxis, Año 19, No 2, 2013, pp. 3 - 52

ISSN 0717 - 2877

Universidad de Talca - Facultad de Ciencias Jurídicas y Sociales

"La capacidad extrapatrimonial de los niños y

adolescentes conforme a sus condiciones de madurez"

Rodrigo Barcia Lehmann

\title{
LA CAPACIDAD EXTRAPATRIMONIAL DE LOS NIÑOS Y ADOLESCENTES CONFORME A SUS CONDICIONES DE MADUREZ*
}

\author{
CHILDREN'S AND ADOLESCENTS PECUNIARY \\ CAPACITY UNDER THEIR CONDITIONS OF MATURITY
}

Rodrigo Barcia LeHMANn**

\begin{abstract}
RESUMEN
Este artículo aborda las condiciones de madurez como un canon preferente para determinar la capacidad extrapatrimonial respecto de los menores de edad, distinguiendo entre niños y adolescentes. Al efecto se ha diferenciado entre la capacidad patrimonial que se ejerce en Chile a través de la patria potestad y la capacidad extrapatrimonial que se ocupa del ejercicio progresivo de los derechos de la infancia y su ejercicio por los adolescentes y, en menor medida, por los niños. Para ello se recurre a la CDN y a las recientes Leyes sobre Matrimonio Civil y sobre Tribunales de Familia.

ABSTRACT

This article discusses the condition of maturity as a preferred canon to fix the ability extra-patrimonial regarding minors, distinguishing between children and adolescents.

For this purpose it has differentiated between patrimonial capacity, exercised in

Chile across parental authority ('patria potestad') and extra-patrimonial capacity, which deals with the progressive realization of children's rights and their exercise by adolescents and in lesser extent by the proper children. This is done, by resorting to the CRC and the recent Law on Civil Marriage and Family Courts Act.
\end{abstract}

\footnotetext{
* Trabajo recibido el 02 de julio y aprobado el 13 de septiembre de 2013.

Abreviaturas: AP: Audiencia Provincial (Corte de Apelaciones española); BGB: Bürgerliches Gesetzbuch (Código Civil alemán); CCCh: Código Civil chileno; CCE: Código Civil español; Codice Civile: Código Civil italiano (1942); CDN: Convención de Naciones Unidas sobre Derechos del Niño (de 27 de noviembre de 1990); C del T: Código del Trabajo (Chile); CIADH: Corte Interamericana de Derechos Humanos; CPE: Constitución Política del Estado (Chile); CA: Corte de Apelación (Chile); CS: Corte Suprema (Chile); LA: Ley de Adopción (Ley No 19.620/1999); LF: Ley de Filiación (Ley No 19.585/1998); LO: Ley orgánica; LMC: Ley de Matrimonio Civil (Ley No 19.947/2004); LO: Ley orgánica; LPM: Ley de Protección de Menores; LTF: Ley de Tribunales de Familia (Ley No 19.968/2004); TC: Tribunal Constitucional; TS: Tribunal Supremo español (equivalente a nuestra Corte Suprema).

** Licenciado en Ciencias Jurídicas y Sociales, Universidad Central de Chile, 1991. MBA Economía y Dirección Internacional de Empresas, MEDI, Universidad Autónoma de Madrid, 1997. European Master in Law and Economics, Complutense und Hamburg Universität, 1998. Doctor en Derecho Civil, Universidad Complutense de Madrid, 2002. Profesor de Derecho Civil Jornada Completa, Facultad de Derecho, Universidad Finis Terrae. Correo electrónico: rbarcia@uft.cl.
} 
PaLABRAS Clave

Capacidad, Ejercicio de derechos fundamentales de la infancia, Patria potestad.

KEYWORDS

Capacity, Exercise of fundamental rights of children, Parental authority.

\section{Planteamiento del problema}

La capacidad en el Derecho comparado ha sufrido una gran cantidad de modificaciones. Hasta hace muy poco se sostenía que la capacidad era una sola y se regulaba en el acto jurídico con efectos generales; pero los procesos de industrialización de los siglos pasados llevaron al establecimiento de un sinnúmero de estatutos particulares, que terminaron mermando la regulación de la capacidad en el acto jurídico, como los que operan en la responsabilidad penal, extracontractual, laboral, etc. Ello acabaría, en definitiva, socavado las reglas de la capacidad propias del Derecho civil-patrimonial clásico. Esta pluralidad de regulaciones ha llevado a que una parte importante de la dogmática civil haya comenzado a poner en duda el que la capacidad, sustentada en criterios netamente patrimoniales, sea la regla general' ${ }^{1}$ El Derecho patrimonial clásico ordenó las reglas que determinaban la capacidad en el acto jurídico, centrándose en la capacidad de ejercicio, por cuanto a toda persona se le concede capacidad de goce ${ }^{2}$. Y, entre nosotros, la incapacidad de ejercicio se determinó

\footnotetext{
${ }^{1}$ Las reglas de la capacidad patrimonial o del acto jurídico se rigen por la fijeza y el automatismo, y ello es evidente desde que la capacidad es un supuesto básico de actuación del mundo de los negocios, que exige un alto grado de seguridad jurídica. A este respecto, De Castro señalaba que, en el Derecho histórico, "[e]l menor, como persona, es capaz de obrar jurídicamente desde que tiene conocimiento de lo que hace y sabe hablar (hay nota al pie), pues es libre y capaz de consejo (hay nota el pie). Esta capacidad de obra estaba limitada en cuanto el menor es persona protegida por el Derecho..." (lo señalado entre paréntesis y cursiva es mío). De Castro trae a colación esta referencia al Derecho español anterior a la codificación. Y señalaba que los menores en el Code son sólo incapaces en lo relativo a su interés, como se destaca en la exposición de motivos de dicho cuerpo legal. Otros autores, sin desconocer esta capacidad, señalan que ella es más restringida. En este sentido, LETE señala que "... después de las recientes reformas del Código civil (Leyes de 13 de mayo y 7 de junio de 1981 y 24 de octubre de 1983), no ofrece duda que en la actualidad el menor de edad no puede ser Ilamado incapaz a no ser que sea expresamente incapacitado". Y para concluir agrega que la capacidad restringida o limitada del menor es la regla general. De CASTRO y Bravo, Federico, Derecho Civil de España, tomo II, Derecho de la Persona. Parte Primera, La Persona y su Estado Civil, Madrid, España, Instituto de Estudios Políticos, 1952, pp. 170 y 172; Lete del Río, J M, Derecho de la Persona, $2^{\mathrm{a}}$ edición, Tecnos, Madrid, 1986, p. 65.

2 Esta tendencia, como destaca Díez-Picazo siguiendo a De Castro, diferencia claramente aptitud de capacidad. Para el autor precedente la concepción patrimonial de la capacidad rehúye de una concepción ius naturalista de la persona. La capacidad negocial no podría sustentarse en una especie de aptitud natural, que se base en la medición de las condiciones psíquicas concretas de los sujetos. Así, Díez-Picazo señala que "[m]uchos tratadistas posteriores, olvidando o desconociendo los sabios consejos de De Castro, han vuelto a la idea de la conexión entre capacidad y aptitud natural. Es verdad
} 
conforme a la pubertad, distinguiéndose, de acuerdo al artículo 26 del CCCh, entre infante o niño, simplemente impúber y menor adulto ${ }^{3}$. Esta forma de abordar la capacidad -conforme a estancos de edades claros- se tornó insostenible para resolver los variados problemas que se presentan en el ámbito de los derechos extrapatrimoniales. La forma clásica de entender la incapacidad chocó con el Derecho moderno, o posmoderno que centró su eje en los derechos fundamentales o de la personalidad, y no en los derechos patrimoniales o del patrimonio ${ }^{4}$. Ello ha conducido a separar las reglas de la capacidad en el acto jurídico, de las que rigen la capacidad en el campo extrapatrimonial, de los derechos de la personalidad o los derechos fundamentales. Desde este prisma se ha llegado a analizar la capacidad conforme al principio de igualdad. Y, autores como Ramos Chaparro, se preguntan ¿cómo se aplica el principio de igualdad respecto de los menores y mayores? ${ }^{5}$. Así, se ha entendido que,

que algunas leyes modernas y algunas modernas reformas de los códigos han utilizado, con referencia a los menores, las Ilamadas 'condiciones de madurez', pero es verdad también que esta idea se ha utilizado para permitir el ejercicio de derechos o para excluir determinados actos de la representación legal (confróntese art. 162), lo que, en buena medida, deja el problema incólume". Díkz-PICAzo, Luis, "Capacidad civil y capacidad penal", en Ruiz-Gallardón, Isabel y García de Pablos, Antonio (editores), Los menores ante el Derecho, Servicio de Publicaciones Facultad de Derecho, UCM, Jaén, España, 2005, p. 12.

${ }^{3}$ Estas distinciones, que provenían del Derecho romano, fueron adoptadas por la mayoría de los códigos Latinoamericanos, como los Códigos Civiles argentino, colombiano, chileno y venezolano; no así en España y en Francia. En Francia el ex artículo 1263, № 1 establecía la minoría de edad como una forma de incapacidad por inidoneidad consensual; y el actual art. $1124.2^{\circ}$ del Code (modificado por la Loi $N^{\circ}$ 68-5 du 3 janvier 1968-art. 2) se refiere a los menores no emancipados, como los menores de dieciocho años. En: http://legifrance.org/affichCodeArticle.do?idArticle=LEGIARTI00000643618 $6 \&$ cidTexte $=$ LEGITEXT000006070721\&dateTexte $=20130802 \&$ oldAction=rechCodeArticle [visitado el 11/03/2013].

${ }^{4}$ En España, Ramos Chaparro hace un análisis de la capacidad, mirada desde un prisma constitucionalcivil, que nos invita a abordar la capacidad desde los derechos fundamentales. De este modo, el referido autor señala que "[p]odrá decirse, gráficamente, que, para lo que le favorece, el menor es igual que el mayor, mientras que para lo que le perjudica es, generalmente, de mejor condición. Pero esta forma de expresar las relaciones entre edad e igualdad, extraída del ámbito civil patrimonial, no puede generalizarse a todo el Derecho privado, ni resulta operativa en el campo político-social. Pese a su fondo de verdad práctica y a su importancia técnica (ya que el favor incapacis enmarcado en el régimen general de las obligaciones y contratos revela el carácter personalista del Derecho civil en todas sus instituciones), la idea del menor como 'inferior favorecido', está impregnada de un cierto paternalismo jurídico, que conduce al prejuicio simplificador de concebir la minoría de edad como un puro privilegio, o un estatuto excepcionalmente protegido. La realidad, sin embargo, es más compleja, y, tanto a nivel legislativo como sicológico desmiente a cada paso aquella idílica convivencia, teóricamente posible, entre el principio de igualdad, la diversa consideración jurídica de las edades y la protección integral de la persona". Ramos Chaparro, Enrique, "Niños y jóvenes en el Derecho civil constitucional", Revista Derecho Privado y Constitución, 3, 7, 1995, p. 171.

${ }^{5}$ La aplicación de este principio a la infancia y adolescencia la hace Ramos Chaparro. Al efecto el citado autor señala que "... los menores son iguales a los mayores en cuanto a la capacidad jurídica y a la titularidad de los derechos de la personalidad, pero son distintos e inferiores a éstos en cuanto a 
a pesar de que los mayores tienen una capacidad de ejercicio más extendida que los menores, ambos son y deben ser tratados de forma igualitaria por el ordenamiento jurídico, es decir, como seres humanos que tienen derechos y pueden ejercerlos, conforme a las condiciones que para ello el sistema jurídico les reclama ${ }^{6}$. Naturalmente, los supuestos para ejercer los derechos por parte de los menores son más exigentes. Esta tendencia ha llevado a que el Derecho moderno acentúe la necesidad de crear las condiciones que permitan que los menores desarrollen tempranamente su personalidad. Ello nos hace preguntarnos: ¿cómo se fomenta el desarrollo de los derechos extrapatrimoniales de la infancia y adolescencia en un ordenamiento jurídico como el nuestro? ${ }^{7}$ Para responder esta pregunta, el artículo que les presento se divide en dos partes. En la primara se aborda el principio del ejercicio progresivo de los derechos del niño y del adolescente y las distintas formas de determinar la capacidad, fundamentalmente respecto de los adolescentes. A su vez, en la segunda parte se analizan las condiciones de madurez, como un criterio fundamental para determinar la autonomía en el ejercicio de los derechos de la infancia. De este modo, se estudiarán dichas condiciones de madurez como un criterio para oír al menor y de determinación de su autonomía.

PRIMERA PARTE:

EL PRINCIPIO DEL EJERCICIO PROGRESIVO DE LOS DERECHOS DEL NIÑO Y DEL ADOLESCENTE Y LAS DISTINTAS FORMAS PARA DETERMINAR SU CAPACIDAD

Este acápite se ocupa brevemente del principio del ejercicio progresivo de los derechos del niño y del adolescente. No es del caso desarrollar este princi-

la capacidad de obrar y en cuanto al ámbito de su responsabilidad subjetiva", agregando más adelante que el principio de igualdad se configura conforme a criterios formales y materiales. Así, para el referido autor, una absoluta igualdad entre ambas categorías -mayores y menores de edad-iría naturalmente en perjuicio del menor; pero además ello impediría su desarrollo gradual e integral como persona. Ramos, "Niños y jóvenes", cit. nota n. 4, p. 181.

${ }^{6}$ Para los efectos de los derechos constitucionales de la infancia, como derechos constitucionales autónomos y especialmente relevantes en tratamientos médicos consultar: CilLero, Miguel, "El Interés Superior del Niño en el Marco de la Convención Internacional sobre los Derechos del Niño", Justicia y Derechos del Niño, № 9, UNICEF, Santiago de Chile, 2007, pp. 125-130, y Lovera Parmo, Domingo A., "Niño, adolescente y derechos constitucionales: de la protección a la autonomía", en Cillero, Miguel (director), Justicia y Derechos del Niño, número 11, UNICEF, Santiago de Chile, 2009, pp. 1154 (también disponible en http://www.unicef.org/argentina/spanish/Justicia_y_Derechos_11_web.pdf [visitado el 13/03/2013]).

7 Barcia Lehmann, Rodrigo, "Informe en Derecho sobre la capacidad de los menores para recibir la denominada píldora del día después", Revista de Chilena de Derecho Privado, 7, 2006, pp. 137-158; "Fallos y comentario a los fallos de la Corte de apelaciones de Santiago y Corte Suprema sobre recurso de protección, interpuesto por la distribución de laboratorios de la denominada píldora del día después a adolescentes (menores mayores de catorce años)", Revista lus et Praxis, 13, 2007, pp. 409-422. 
pio, sino relacionarlo con una serie de conceptos objetivos que lo llenarán de contenido. De este modo, se presentarán criterios que el juez puede ponderar al momento de determinar el rango de autonomía del niño o del adolescente, que van desde el deber de escuchar al niño, complementar su voluntad o darle total autonomía respecto del caso específico que se le presenta, excluyéndose la representación de los padres.

\section{EL PRINCIPIO DEL EJERCICIO PROGRESIVO}

DE LOS DERECHOS DE LA INFANCIA Y ADOLESCENCIA

El interés superior del niño se concretiza, en materia de capacidad, en el principio del ejercicio progresivo de los derechos del niño y del adolescente. Esta tendencia no es nueva en el Derecho moderno, como se puede apreciar de las constantes reducciones de la mayoría de edad ${ }^{8}$. Este principio comenzó afectando fundamentalmente la facultad de representación que tienen los padres respecto de sus hijos; pero terminó con alcanzar a todo el resto de facultades y deberes de la filiación, como la educación, la libertad religiosa, etcétera, y excluyendo la representación legal del campo extrapatrimonial. El principio del ejercicio progresivo de los derechos de la infancia se desprende claramente del Derecho chileno (artículos $222.2^{\circ}, 234.2^{\circ}, 242.2^{\circ}$ y 245 del CCCh; $3.1^{\circ}, 27.2^{\circ}$,

\footnotetext{
${ }^{8}$ De este modo, en Chile, como en el Derecho Comparado, la mayoría de edad ha sido continuamente reducida. En el Código de Bello la mayoría de edad se alcanzaba a los veinticinco años. El antecedente inmediato de la edad de veinticinco años para alcanzar la mayoría de edad estaba en las Siete Partidas. Antes de ellas, en el Derecho histórico, la mayoría de edad se alcanzaba a los veinte años en el Fuero Juzgo y el Fuero Real y a los dieciséis años en el Fuero de Castilla. A su vez, la Ley $N^{\circ} 7.612$, de 21 de octubre de 1943, rebajó la edad a veintiún años de edad, y, finalmente, la Ley № 19.221, de 1 de junio de 1993, estableció el actual límite de la mayoría de edad a los dieciocho años. Pero el límite de edad en los veinticinco años obedecía al poder del padre respecto del hijo, más que una real incapacidad del hijo.

Rivera nos señala al respecto que "[d]ecía el maestro Bello en el Párrafo XVI del Mensaje con que se acompañó el Proyecto de Código Civil chileno al Congreso Nacional: 'La mayor edad, fijada a los veinticinco años, emancipa por el ministerio de la ley al hijo de familia. Esto sólo mejoraría ya entre nosotros su condición, pues, como sabéis, no hay por la sola edad límite alguno para ese estado de dependencia según las leyes romanas y patrias. Varios códigos modernos han abreviado mucho más la duración de la patria potestad paterna...'". Castán explica la pérdida constante de poder del padre sobre su descendencia como un aporte del cristianismo que enfrentaría al sistema romano-patriarcal de Derecho de Familia. En este sentido, Castán señala que "[c]ierto es que las orientaciones familiares cristianas son incompatibles con la antigua concepción del poder paternal. Y habiendo el cristianismo inspirado, en general, las grandes concepciones del sistema jurídico occidental, hay que admitir que ha influido considerablemente en la evolución de la patria potestad". CASTÁN VÁsQUEZ, José María, "Título VI del Libro I del CCE", en Albaladejo, Manuel, (editor), Comentarios al Código Civil y Compilaciones Forales, tomo III, volumen 2, Editorial Revista de Derecho Privado, Madrid, 1982, p. 74, y RIVERA ResTrePo, José Maximiliano, "La Patria Potestad y los Derechos Fundamentales", Revista Chilena de Derecho de Familia, 2, 2011, pp. 5, 25 y 28 (en proceso de publicación).
} 
$54.1^{\circ}, N^{\circ} 5$ y $6,74.3^{\circ}$ y $85.2^{\circ}$ de la $L M C$ y 15 y 16 de la $L T F$ y, especialmente del preámbulo y artículos 3, 5 y 12 de la $C D N^{9}$.

La importancia de este principio es evidente desde que el campo de los derechos de la personalidad determinará la forma en que se ejercen los derechos de naturaleza extrapatrimonial. Ramos Chaparro ordena estos derechos, protegidos por la $C D N$, como el derecho a la propia identidad (artículos 7 y 8 de la Convención); derecho a la compañía de los padres (artículos 9 y 10 de la Convención); derecho a la protección y asistencia del Estado (artículo 20 de la Convención) y derecho a un nivel de vida adecuado para su desarrollo físico, mental, espiritual, moral y social (artículo 27 de la Convención) ${ }^{10}$. En este mismo sentido la $C I A D H$, en el caso de los hermanos Gómez Paquiyauri, (...), párr. 124; Caso Bulacio, (...), párr. 134 y Condición Jurídica y Derechos Humanos del Niño, (...), párr. 56, ha resuelto que "[e]n esta materia, cuando se trata de la protección de los derechos del niño y de la adopción de medidas para lograr dicha protección, rige el principio del interés superior del niño, que se funda en la dignidad misma del ser humano, en las características propias de los niños y en la necesidad de propiciar el desarrollo de éstos, con pleno aprovechamiento de sus potencialidades (lo destacado en cursiva es mío)"11.

El origen de este principio se encuentra en los países anglosajones, que fueron los primeros en establecerlo ${ }^{12}$ y su consagración internacional se plasmó en

\footnotetext{
${ }^{9}$ No es del caso ahondar en esta materia ya abordada en: BARCIA, "Informe", pp. 141-145 y "Fallos", pp. 152-156 (ambas cit. nota n. 7).

${ }^{10}$ Ramos, "Niños y jóvenes", cit. nota n. 4, pp. 199 y 200.

${ }^{11}$ En igual sentido se puede recurrir a la Opinión Consultiva n. 17 de 2002, emanada de la CIADH, de 28 de agosto de 2002, solicitada por la Comisión Interamericana de Derechos Humanos. En: www. corteidh.or.cr_docs_opiniones_seriea_17_esp [visitado el 02/04/2013]; y la Observación General № 12 (2009) sobre el derecho del niño a ser escuchado, del Comité de los Derechos del Niño, $51^{\circ}$ período de sesiones, Ginebra, 25 de mayo a 12 de junio de 2009. En: http://www.observatoriodelainfanciadeasturias.es/foromunicipal/2011/01/observacion-general-n\%C2\%BA12-del-comite-de-los-derechosdel-nino-el-derecho-del-nino-a-ser-escuchado/ [visitado el 11/03/2013].

${ }^{12}$ El origen del denominado Gillick Principle se encuentra en los países anglosajones, que fueron los primeros en consagrarlo. Dicho principio se desprende del juicio "Gillick v. West Norfolk and Wisbech Area Health Authority. House of Lords", [1986] 1 AC 112, [1985] 3 All ER 402, [1985] 3 WLR 830, [1986] 1 FLR 224, [1986] Crim LR 113, 2 BMLR 11. Así, a dicho principio se le conoce en el Reino Unido como "Gillick Principle". En esta causa una madre reclamó ante el Departamento de Salud y Seguridad Social la asesoría prestada a su hija menor -por un médico del referido servicio- en materia de anticonceptivos, sin su consentimiento. En concreto la madre solicitó las siguientes medidas: (i) La declaración de ilegalidad de una circular del referido servicio, que otorgaba información sobre métodos anticonceptivos. La madre fundamentó su demanda en que esta información afectaba al principio del interés del menor y sus propios derechos como madre. (ii) Declarar que la autoridad sanitaria no puede asesorar, ni dar consejos a los menores en materia de relaciones sexuales, métodos anticonceptivos o aborto. En primera instancia, el Juez Woolf J. rechazó la demanda, pero en segunda la Corte la acogió en su totalidad. El Departamento de Salud apeló en contra de la primera pretensión -consignada en el punto i)-, ganando dicha apelación ante la House of Lords, pero la autoridad sanitaria no apeló en
} 
el artículo 5 de la $C D N$. Los Estados Partes, conforme a la norma precedente, respetarán las responsabilidades, los derechos y los deberes de los padres o, en su caso, de los familiares o de la comunidad, según establezca la costumbre local. Además, la disposición precedente agrega que dicha autoridad debe ser ejercida en consonancia con la evolución de sus facultades, dirección y orientación para que el niño ejerza los derechos reconocidos en la Convención ${ }^{13}$. En este mismo sentido, entre nosotros, Cillero señala que "[a]sí, la CDN es portadora e inspiración de una doctrina que considera al niño como un pleno sujeto de derecho, dejando atrás la imagen de niño objeto de representación, protección y control de los padres o el Estado, que informó la legislación de menores en el mundo entero"14.

contra de la segunda. Además, se entabló una acción penal contra el médico que asesoró a la menor y le dio unas píldoras anticonceptivas. El fundamento de la acusación era que dicha actitud era ilegal, porque promovía una conducta tipificada penalmente, como lo es mantener relaciones sexuales con una menor de edad. El Juez Woolf J. rechazó la demanda por considerar que la referida píldora no podía ser considerada como el instrumento del ilícito penal, sino como un paliativo de las consecuencias de éste. Otro argumento relevante fue presentado por la demandante en el sentido que, de acuerdo a la sección 8 (3) de la Ley de Menores de 1969, éstos sólo podían prestar su consentimiento en tratamientos médicos, cirugías y tratamientos dentales, si fuesen mayores de dieciséis años. Pero, por voto de la mayoría la House of Lords rechazó este argumento al estimar que dicha disposición no había sido adecuadamente interpretada. Finalmente, la demandante señalaba que los consejos en materia de tratamiento anticonceptivos constituían una invasión ilegal de sus derechos maternos, que sólo podía ser admitido en casos de urgencia o con autorización del tribunal. Sin embargo, la House of Lords también rechazó la pretensión de la actora, en razón de los siguientes argumentos: (i) no existe una regla que avale un poder absoluto de los padres sobre los hijos hasta cierta edad; (ii) el derecho de los padres a tomar decisiones por sus hijos declina, en la medida que ellos pueden tomar sus propias decisiones fundados en la extensión de su entendimiento y su capacidad para desarrollar sus propias ideas, y (iii) una menor de dieciséis años no solamente por su edad esta privada de la capacidad para recibir consejos en materia de medidas anticonceptivas. BARCIA LeHMANN, Rodrigo y Méndez RoYo, Daniela, "El Principio del Ejercicio Progresivo de los Derechos de la Infancia y Adolescencia desde la Perspectiva de dos Sentencias Paradigmáticas en el Derecho Inglés de la Familia", Revista Chilena de Derecho de Familia, 1, 2010, pp. 117-136.

${ }^{13}$ A este respecto son especialmente interesantes las palabras de Grant, Director Ejecutivo de UNICEF, que tras la ceremonia de firma de la Convención en Nueva York, el 26 de enero de 1990, manifestó: "la Convención ha dado prioridad a los niños en las agendas nacionales e internacionales. La Comunidad Internacional ha proporcionado una base firme para una nueva ética que define al niño como individuo con derechos inalienables no menos valiosos que los del adulto".

También es destacable el trabajo de Herrera que desprende del artículo 5 en comento en lo que se refiere a la "...consonancia con la evolución de las facultades" de los hijos, un imperativo que denomina como supralegal implica el desarrollo de los derechos del niño. HeRrera, MARISA, "La democratización de las relaciones de familia. Desafíos de la relación padres e hijos desde el principio de capacidad progresiva de niños, niñas y adolescentes", en Gómez de LA TORRE VARGAS, Maricruz (Directora), Revista del magíster y doctorado en derecho, $\mathrm{N}^{\circ} 4$, Facultad de Derecho Universidad de Chile, Escuela de Posgrado, 2011, pp. 28-29.

${ }^{14}$ Cillero Bruñol, Miguel, "Infancia, autonomía y derechos: una cuestión de principios", en Boletín del Instituto Interamericano del Niño, № 234, (también disponible en: www.iin.oea.org/Infancia_autonomia_derechos.pdf, p. 5 [visitado el 13/03/2013]). 
En definitiva, el principio en comento nos insta a articular un sistema jurídico que promueva el desarrollo de los derechos de la infancia y adolescencia. Es así como autores como Ramos Chaparro señalan, respecto de esta forma de comprender modernamente la capacidad en el campo de los derechos extrapatrimoniales, que "[e]ste reconocimiento de capacidad, siquiera sea parcial o limitada, a partir de una cierta edad (doce, catorce o dieciséis años) o de un cierto 'grado de madurez', debe interpretarse en la actualidad como una expresión de respeto jurídico al libre desarrollo de la personalidad, en tanto esté fundado realmente en una aptitud psíquica suficiente del sujeto (aunque sea en la forma de 'autogobierno mínimo' o 'incipiente') y persiga una finalidad específicamente favorable al menor en relación con la naturaleza del acto"15. En igual sentido, Herrán indica que "[e]n la actualidad, la tendencia legislativa y el sentir doctrinal han vencido esta tradicional concepción, y el menor es hoy en nuestro ordenamiento jurídico, un sujeto de derechos, cuya capacidad jurídica no se cuestiona, bien al contrario, las distintas experiencias normativas, revelan que la autonomía de los menores crece día a día, y que se ha producido en los últimos tiempos un progresivo incremento de la capacidad contractual de los menores"16.

En Alemania este principio está expresamente consagrado en el $\S 1.626 .2^{\circ}$ del $B G B^{17}$. En consideración a esta norma, el cuidado de los padres debe ejercerse reconociendo una creciente independencia del hijo con relación a ellos. Así, los padres observarán en el ejercicio del cuidado de sus hijos, su creciente capacidad y necesidad de independencia, en cuanto a su actuación consciente y responsable. Además, la disposición precedente agrega que los padres deben debatir con el hijo las cuestiones relativas a su cuidado y promoverán la adopción de acuerdos; aunque, conforme a algunos autores esta norma carecería de eficacia, simplemente se trataría de una norma programática cuyo contenido se completaría con lo establecido en el $\S 1.666$ del $B G B^{18}$. En definitiva, la

\footnotetext{
${ }^{15}$ Ramos, "Niños y jóvenes", cit. nota n. 4, p. 183.

${ }^{16}$ Herrán Ortiz, Ana Isabel, "Nueva perspectiva de la protección jurídica del menor. La experiencia legislativa española", en Lledó Yagüe, Francisco, Sánchez Sánchez, Alicia (directores), Monje Balmaseda, Oscar (coord.), Los 25 temas más frecuentes en la vida práctica del derecho de familia, Tomo I. Parte Sustantiva, Dykinson S.L., 2011, p. 460. Incluso algunas autoras han entendido que la mayoría de edad en el ámbito patrimonial se habría adelantado a los dieciséis años respecto de los actos ordinarios. Linacero De La Fuente, María, "La protección del menor en el Derecho Civil español. Comentario a la Ley Orgánica 1/96, de 15 de enero", Actualidad Civil, 48, 1999, p. 1587.

${ }^{17}$ La norma establece textualmente que "(2) Bei der Pflege und Erziehung berücksichtigen die Eltern die wachsende Fähigkeit und das wachsende Bedürfnis des Kindes zu selbständigem verantwortungsbewusstem Handeln. Sie besprechen mit dem Kind, soweit es nach dessen Entwicklungsstand angezeigt ist, Fragen der elterlichen Sorge und streben Einvernehmen an".

${ }^{18}$ El artículo 1666 del $B G B$ se refiere a la puesta en peligro del bienestar del hijo, tanto en su aspecto patrimonial, como personal.
} 
aludida regla reconoce como límite al cuidado de los padres, la capacidad del hijo, que se va haciendo creciente en la medida que el menor va desarrollando su consciencia. Pero esta no es la única manifestación de este principio en Alemania, por cuanto los adolescentes a la edad de catorce años alcanzan una plena autonomía en ciertas materias, como la religiosa ${ }^{19}$.

El Código de Filiación sueco se refiere brevemente a este principio, estableciendo que "el niño debe ser tratado respetando su persona e individualidad". Aún de forma más clara este criterio se establece como cláusula general en el artículo $371-1^{\circ}$, inciso $3^{\circ}$ del Code francés ${ }^{20}$.

En España este principio se consagraría expresamente en la Ley № 1/1996 sobre Protección Jurídica del Menor ( $L P M)$. Dicha ley resalta la importancia de este principio en su exposición de $\operatorname{motivos}^{21}$. Y en su artículo 2 establece,

${ }^{19}$ De Torres destaca una sentencia del Tribunal territorial de Schlewig (OLG Schkeswig, FamRZ, 2003, p. 1948) por la cual, ante la negativa de un padre a que su hija fuera bautizada por su fe musulmana, el juzgado determinó deferir dicha decisión a la hija hasta que ella cumpliese catorce años. De ToRRES, José Miguel, "Tratamiento del interés del menor en el Derecho alemán", Anuario de Derecho Civil, 61, 2, 2006, p. 716.

${ }^{20}$ En este sentido, la norma precedente establece lo siguiente:

"Art. $371-1^{\circ}$. L'autorité parentale est un ensemble de droits et de devoirs ayant pour finalité l'intérêt de l'enfant.

Elle appartient aux père et mère jusqu'à la majorité ou l'émancipation de l'enfant pour le protéger dans sa sécurité, sa santé et sa moralité, pour assurer son éducation et permettre son développement, dans le respect dû à sa personne.

Les parents associent l'enfant aux décisions qui le concernent, selon son âge et son degré de maturité".

${ }^{21}$ Esta ley, a pesar que es de 1996, describe muy bien la tensión entre la protección de la infancia y el desarrollo de los derechos de la infancia y adolescencia y la necesidad del sistema jurídico de compatibilizar ambas tendencia cuando señala que "[l]as transformaciones sociales y culturales operadas en nuestra sociedad han provocado un cambio en el status social del niño y como consecuencia de ello se ha dado un nuevo enfoque a la construcción del edificio de los derechos humanos de la infancia. Este enfoque reformula la estructura del derecho a la protección de la infancia vigente en España y en la mayoría de los países desarrollados desde finales del siglo XX, y consiste fundamentalmente en el reconocimiento pleno de la titularidad de derechos en los menores de edad y de una capacidad progresiva para ejercerlos. El desarrollo legislativo postconstitucional refleja esta tendencia, introduciendo la condición de sujeto de derechos a las personas menores de edad. Así, el concepto de ser escuchado si tuviere suficiente juicio se ha ido trasladando a todo el ordenamiento jurídico en todas aquellas cuestiones que le afectan. Este concepto introduce la dimensión del desarrollo evolutivo en el ejercicio directo de sus derechos. Las limitaciones que pudieran derivarse del hecho evolutivo deben interpretarse de forma restrictiva. Más aún, esas limitaciones deben centrarse más en los procedimientos, de tal manera que se adoptarán aquéllos que sean más adecuados a la edad del sujeto. El ordenamiento jurídico, y esta Ley en particular, va reflejando progresivamente una concepción de las personas menores de edad como sujetos activos, participativos y creativos, con capacidad de modificar su propio medio personal y social; de participar en la búsqueda y satisfacción de sus necesidades y en la satisfacción de las necesidades de los demás.

El conocimiento científico actual nos permite concluir que no existe una diferencia tajante entre las necesidades de protección y las necesidades relacionadas con la autonomía del sujeto, sino que la mejor forma de garantizar social y jurídicamente la protección a la infancia es promover su autonomía como 
respecto de los principios generales, que "[e]n la aplicación de la presente Ley primará el interés superior de los menores sobre cualquier otro interés legítimo que pudiera concurrir. Asimismo, cuantas medidas se adopten al amparo de la presente Ley deberán tener un carácter educativo.

Las limitaciones a la capacidad para obrar de los menores se interpretarán de forma restrictiva" 22 .

Los menores, en el Derecho español, no serían incapaces, sino que tendrían ciertas limitaciones en cuanto al ejercicio de sus derechos civiles. Estos derechos, conforme al ámbito de aplicación de la ley, no son patrimoniales, y su contenido naturalmente estaría determinado por la regulación de la referida ley $^{23}$. Lo anterior se desprende de los artículos 162 del $C C E, 2.1^{\circ}$ y 3 de la citada $L P M$ española ${ }^{24}$. A su vez, del mensaje de la Ley sobre Protección del Menor es especialmente destacable la parte que establece que "[e]ste enfoque reformula la estructura del derecho a la protección de la infancia vigente en

sujetos. De esta manera podrían ir construyendo progresivamente una percepción de control acerca de su situación personal y de su proyección de futuro. Este es el punto crítico de todos los sistemas de protección a la infancia en la actualidad. Y, por lo tanto, es el reto para todos los ordenamientos jurídicos y los dispositivos de promoción y protección de las personas menores de edad. Esta es la concepción del sujeto sobre la que descansa la presente Ley: las necesidades de los menores como eje de sus derechos y de su protección".

${ }^{22}$ La Ley catalana № 14/2010, de 27 de mayo, sobre derechos y las oportunidades en la infancia y la adolescencia, se refiere a la edad y condiciones de madurez como supuestos habilitantes para el ejercicio de derechos en los artículos $32 ; 35 ; 44.2^{\circ}$, letra e); $47.1^{\circ}$ y $117.1^{\circ}$. En este sentido es destacable el artículo $44.2^{\circ}$, letra e), que establece respecto del derecho a la prevención, la protección y la promoción de la salud que "[c]ualquier niño o adolescente tiene derecho a: d) Recibir información sobre su salud y sobre la atención sanitaria que recibe, y a poder participar en su proceso asistencial de manera adecuada a su edad y grado de madurez" (lo destacado en cursiva es mío). A su vez, la Ley aragonesa $N^{\circ} 13 / 2006$, presume la aptitud del menor que ha cumplido los catorce años, no incapacitado, para entender y querer un acto (de los que puede realizar) mientras no se demuestre lo contrario.

${ }^{23}$ Este aspecto no ha estado exento de problemas por cuanto la referencia a los derechos de la personalidad que hace la ley es limitada. Ello ha llevado a la doctrina española a plantearse lo que sucede con los derechos de la personalidad que no están enumerados en la ley.

24 "Artículo 3. Referencia a Instrumentos Internacionales.

Los menores gozarán de los derechos que les reconoce la Constitución y los Tratados Internacionales de los que España sea parte, especialmente la Convención de Derechos del Niño de Naciones Unidas y los demás derechos garantizados en el ordenamiento jurídico, sin discriminación alguna por razón de nacimiento, nacionalidad, raza, sexo, deficiencia o enfermedad, religión, lengua, cultura, opinión o cualquier otra circunstancia personal, familiar o social.

La presente Ley, sus normas de desarrollo y demás disposiciones legales relativas a las personas menores de edad, se interpretarán de conformidad con los Tratados Internacionales de los que España sea parte y, especialmente, de acuerdo con la Convención de los Derechos del Niño de Naciones Unidas de 20 de noviembre de 1989.

Los poderes públicos garantizarán el respeto de los derechos de los menores y adecuarán sus actuaciones a la presente Ley y a la mencionada normativa internacional". 
España y en la mayoría de los países desarrollados desde finales del siglo XX, y consiste fundamentalmente en el reconocimiento pleno de la titularidad de derechos en los menores de edad y de una capacidad progresiva para ejercerlos" (lo destacado en cursiva es mío) ${ }^{25}$. A pesar de que algunos autores suelen incorporar este principio a través del interés del niño ${ }^{26}$, su reconocimiento en el Derecho comparado como un principio autónomo no se ha hecho esperar. Así, en el orden judicial español, esta capacidad fue tempranamente reconocida por las sentencias, de 17 de septiembre de 1996 y 11 de junio de 1998, de la Sala Civil del Tribunal Supremo español. Los fallos precedentes reconocen la existencia de una capacidad progresiva del menor para ejercer sus derechos. La primera de estas sentencias ( $N^{\circ} 713 / 1996$ del TS, Sala 1 ${ }^{a}$, de lo Civil, 17 de septiembre de 1996) subsume el principio del ejercicio progresivo de los derechos del niño en el interés superior, resolviendo que "...ello no quiere decir que se desconozca por el órgano colegiado (se refiere a la Audiencia Provincial) el interés superior del menor como principio inspirador de todo lo relacionado con él, que vincula al juzgador, a todos los poderes públicos e, incluso, a los padres y ciudadanos, con reconocimiento pleno de la titularidad de derechos en los menores de edad y de una capacidad progresiva para ejercerlos, de manera que han de adoptarse aquellas medidas que sean más adecuadas a la edad del sujeto para ir construyendo progresivamente el control acerca de su situación personal y proyección de futuro..." (lo destacado entre paréntesis y cursiva y sólo en cursiva es mío). A este respecto, autores como Núñez Muñoz y Jordano Fraga agregan que la capacidad general del menor no emancipado, además de ser por definición de ámbito limitado, sería variable o flexible, en función del grado de desarrollo intelectivo y personal que socialmente corresponde a cada edad. Por otra parte, en el Derecho español, algunos autores señalan que el menor es por regla general incapaz, pero puede ejercer sus derechos personalmente en la medida que su madurez se lo permita ${ }^{27}$.

\footnotetext{
${ }^{25}$ Párrafo $4^{\circ}$ del $N^{\circ}$ II de la exposición de motivos del mensaje de referida Ley sobre Protección Jurídica del Menor.

${ }^{26}$ Rivero Hernández, Francisco, El Interés del Menor, Madrid, Dikinson, 2000, pp. 108-112.

${ }^{27}$ De acuerdo a Lete del Río, el desarrollo de la razón y voluntad humana o capacidad natural se adquieren con la mayoría de edad. Pero, los derechos se pueden ejercer antes de la referida edad, si el menor cuenta con las condiciones de desarrollo y madurez necesarias para el ejercicio de los derechos. Además, el referido autor indica que dicho desarrollo y madurez se puede alcanzar a través de la emancipación o anticipación de la mayoría de edad, conocida como capacidad de obrar limitada. Pero el aludido autor posteriormente extiende los supuestos de la denominada capacidad de obrar limitada a la posibilidad de realizar actos o negocios jurídicos concretos, como en el caso del artículo 1329 del CCE. En este sentido, Lete del Río parece entender que la capacidad de los menores es bastante restringida al limitarla a los dos supuestos precedentemente aludidos. Sin embargo, Lete del Río agrega que cada persona, dentro de su estado civil, tiene la capacidad de obrar que le corresponde, según su capacidad natural. Así, Lete del Río entiende que la capacidad varía de los siete años a los dieciséis,
} 
La consagración de este principio, como independiente, naturalmente nos lleva a preguntarnos ¿hasta qué punto un adolescente e incluso un niño, en ejercicio de su esfera de autonomía, puede decidir actuar contra su propio interés? Esta decisión del menor es única y no puede ser ejercida a través de la representación, ya que la patria potestad o tutela deben ejercerse conforme a dicho interés. En otras palabras, el representante no puede actuar contra el interés concreto del niño, motivado, por ejemplo, por un interés superior. Por ello es relevante responder si es posible que un menor, decidiendo en su ámbito privado de autonomía, pueda atentar contra sus propios intereses. Ello acontece cuando los menores actúan motivados por un interés superior a ellos mismos, como podría ser salvar a sus padres o a un hermano mediante una donación de órganos ${ }^{28}$. No es del caso tratar dicho supuesto específicamente en este trabajo, que es de por sí complejo; pero su sólo planteamiento destaca la importancia de la determinación del ámbito de autonomía del niño o del adolescente o de su capacidad, si se quiere, en materia de derechos extrapatrimoniales.

En todo caso, como una respuesta parcial a la pregunta precedente, se puede señalar que el principio del ejercicio progresivo de los derechos del niño y del adolescente trae aparejada como consecuencia el desarrollo de su personalidad por etapas ${ }^{29}$. La primera en manifestarse sería el derecho del menor a ser oído ${ }^{30}$.

independientemente que se tenga el mismo estado civil y de igual manera, la falta de capacidad física o psíquica es el presupuesto de la incapacidad. LeTE, Derecho de la, cit. nota n. 1, pp. 26-27.

${ }^{28} \mathrm{~A}$ este respecto De Torres nos señala una interesante sentencia en consideración a la cual un tribunal de familia alemán, mediante informe de peritos, determinó que el interés del niño era contrario a lo que él mismo había manifestado, por cuanto había sido manipulado por uno de sus padres. La sentencia fue pronunciada el año 2003 por el tribunal de Familia de Schleswig. Un menor de diez años manifestada su conformidad al cambio de cuidad del padre, que detentaba su cuidado; pero en realidad extrañaba el entorno de la familia materna. Este caso es interesante porque el menor se manifestaba de acuerdo con la decisión paterna, pero de su perfil psicológico se desprendía que no se había adaptado al cambio y que extrañaba el entorno de su madre. La opinión del menor sólo reflejaba su solidaridad y fidelidad al padre, no sus propios intereses. De Torres, J., "Tratamiento", cit. nota n. 19, p. 715.

${ }^{29}$ Ramos Chaparro distingue en el Derecho español dos etapas. La primera fase (infancia) admitiría la representación sólo en favor del menor, en casos como adopción (art. 177.1 $1^{\circ}$ del CCE), posesión (art. 443 del $C C E$ ), donación pura (art. 626 del $C C E$ ), etc. La segunda fase estaría configurada por la menor edad (pubertad o juventud), que estaría caracterizada por una capacidad limitada o semicapacidad. La base de esta etapa es "...la capacidad natural del sujeto para entender y querer". En igual sentido Rivero distingue en torno a la participación del menor las siguientes etapas: "(i) unas veces sí existirá, con decisión suya en forma efectiva y directa (ejercicio de ciertos derechos, que únicamente a él compete); (ii) otras veces, sólo indirectamente participa (más que decide) en cuanto que los padres no pueden hacerlo en su interés sin contar con él (tras oírle, atendiendo en lo posible a sus sentimientos o deseos, cuando éstos lo merezcan); (iii) en alguna ocasión, en cuanto la decisión de los padres no es libre, sino condicionada por el necesario respeto de su personalidad". Ramos, "Niños y jóvenes", cit. nota n. 4, p. 185; RIVERO, El Interés, cit. nota n. 26, p. 297.

${ }^{30}$ En este sentido, cabe tener presente el párrafo 21 de la Observación General № 12 (2009), que dispone: "[e]l Comité hace hincapié en que el artículo 12 no impone ningún límite de edad al dere- 
El peldaño siguiente en esta graduación del ejercicio de los derechos del niño, exige que en ciertos actos, además de la voluntad del o de los representantes de éste, deba concurrir la voluntad del menor para completar su capacidad de ejercicio, como, por ejemplo, sucede en el Derecho comparado en los artículos $162.3^{\circ}$ del CCE y 156 del Código de Familia de Cataluña ${ }^{31}$. Finalmente, este principio se desarrolla completamente a través del reconocimiento de una esfera de autonomía del menor, en aquellos campos en que éste posea las condiciones de madurez que el acto exige ${ }^{32}$. Sin embargo, aun en los casos que el adolescente cuente con la madurez suficiente, la entidad del acto puede ser de tal relevancia para su futuro, que se desestime su capacidad. Sin perjuicio de este último aspecto, lo que se analiza en este trabajo es la aplicación escalada de la autonomía del niño y del adolescente y la forma en que se concreta la capacidad extrapatrimonial en nuestro Derecho.

El límite entre la etapa por la cual el niño debe ser escuchado y la que lo autoriza a actuar, con un menor o mayor grado de independencia, no es del todo claro y varía en cada ordenamiento jurídico; sin perjuicio de lo cual se

cho del niño a expresar su opinión y desaconseja a los Estados partes que introduzcan por ley o en la práctica límites de edad que restrinjan el derecho del niño a ser escuchado en todos los asuntos que lo afectan".

${ }^{31}$ Observación General № 12 (2009) sobre el derecho del niño a ser escuchado, del Comité de los Derechos del Niño, cit. nota n. 11.

El artículo 156 del Código Civil de Familia de Cataluña se refiere al "conocimiento suficiente" en lugar de las condiciones de madurez como condición determinante de la capacidad del menor. En virtud de dicho artículo cualquier acto que implique alguna prestación personal de los hijos, si éstos tienen menos de doce años y tienen suficiente conocimiento requiere de su consentimiento. En este sentido, el Codi no se refiere, ni a las condiciones de madurez, ni al suficiente juicio. Esta disposición sería similar a la norma del artículo $162.3^{\circ}$ del $C C E$, pero se diferenciaría en que en el Código civil español los contratos que contengan prestaciones personales exigen el consentimiento del menor siempre que tuviere "suficiente juicio" e independientemente de su edad. En esta etapa es posible distinguir una sub-etapa, mediante la cual el menor podrá directamente ejercer sus derechos, pero requiere de algún complemento a su voluntad. Ver: cit. nota n. 33.

32 NúÑez MuÑIz, Carmen, "Algunas Consideraciones sobre la Ley Orgánica 1/1996 de 15 de enero, de Protección Jurídica del Menor", La Ley, Diario Nº 4.135, de 2 de octubre de 1996, p. 1.483.

Estas dos últimas etapas se desprenden de lo preceptuado en los artículos $162.2^{\circ} \mathrm{N}^{\circ} 3$ y $177.1^{\circ}$ del $C C E$, en virtud del cual el adoptado mayor de doce años deberá consentir la adopción frente al Juez y $3.1^{\circ}$ de la Ley $N^{\circ} 1 / 1982$ sobre Derecho al Honor y a la Propia Imagen o de la exposición de motivos de la Ley $N^{\circ} 1 / 1996$. Asimismo, el menor puede entablar directamente ciertas acciones, como las señaladas en los artículos 158, 160, 167 y 248 del CCE.

Finalmente, es muy relevante traer a colación el fallo del Tribunal Constitucional № 141/2000 de 29 de mayo. La referida sentencia establece que "[l]os menores de edad son titulares plenos de sus derechos fundamentales, en este caso, de sus derechos a la libertad de creencias y a la integridad moral, sin que el ejercicio de los mismos y la facultad de disponer sobre ellos se abandonen por completo a lo que al respecto puedan decir aquéllos que tengan atribuida su (...) patria potestad, cuya incidencia sobre el disfrute del menor de sus derechos fundamentales se modulará en función de la madurez del niño y los distintos estadios en que la legislación gradúa su capacidad de obrar" (lo destacado en cursiva es mío). 
pueden detectar algunas directrices a este respecto. En otros Derechos, como el español, ello se puede hacer diferenciando entre "suficiente juicio" y "condiciones de madurez". De esta forma, el suficiente juicio determina la necesidad de escuchar al niño y las condiciones de madurez determinan su grado de autonomía o de capacidad en el ámbito extrapatrimonial ${ }^{33}$.

Sin perjuicio de la diversidad de opiniones planteadas previamente, aun para los autores que señalan que estos términos son sinónimos, no se puede dejar de lado que las condiciones de madurez operan sobre actos que no son susceptibles de representación, como son los actos personalísimos ${ }^{34}$. En cambio, casi la

${ }^{33}$ Esta discusión se ha producido en España en los siguientes términos. Una parte importante de la doctrina considera sinónimos estos conceptos. De esta opinión parecen ser Bo Jané y Caballero al referirse indistintamente a las condiciones de madurez y al suficiente juicio, como condición para que el menor sea oído. Bo Jané, M. y Caballero, R., "El Nuevo Derecho del Menor a ser Oído: ¿Sujeto Activo en la Determinación de sus Intereses?", Revista Jurídica Española La Ley, 1.996-6, La Ley, Actualidad Civil, p. 1493. En igual sentido F. Rivero Hernández señala que para poder juzgar el "discernimiento o madurez de juicio" del menor se le exige "una mínima racionalidad de opinión u opción del menor: es decir, que el deseo por él expresado sea congruente con los fines contemplados por esa persona (...) que las metas marcadas o deseadas por el menor en cuestión sean razonablemente alcanzables y realizables...". Rivero, El Interés, cit. nota n. 26, p. 221. Por otra parte, De Prada González plantea que es discutible el determinar si el tener suficiente juicio (conforme al artículo 162. inc. final del CCE) es equivalente a las condiciones de madurez. De PradA GonZÁlez, J. M., pp. 392 y 393 y ZarraluquI, "El tratamiento de los menores y los jóvenes", en Comentarios vLex (30 de septiembre de 2009), p. 4. En: http://prensa.vlex.es/vid/zarraluqui-eznarriaga-abogados-67460961 [visitado el 16/03/2013]. Para el referido autor el tener suficiente juicio es más amplio que las condiciones de madurez. Igual posición parece seguir Zarraluqui cuando señala que "[e]n otras ocasiones, cada vez más numerosas, complementa el criterio exacto y seguro de la edad, con otro indeterminado y relativo: el suficiente juicio del menor, parecido pero no igual a su madurez...". Bo Jané y Caballero, "El Nuevo", cit. nota n. 33, p. 1493.

${ }^{34}$ En la exposición de motivos de la Ley española sobre Protección Jurídica del Menor se remite de "capacidad progresiva para ejercer los derechos de que es titular...". Pero, además el artículo 162.2, № 1 del CCE excluye los actos personalísimos expresamente de la representación de los padres. La norma en comento es del siguiente tenor:

"Artículo 162.

Los padres que ostenten la patria potestad tienen la representación legal de sus hijos menores no emancipados. Se exceptúan:

1. Los actos relativos a derechos de la personalidad $u$ otros que el hijo, de acuerdo con las Leyes y con sus condiciones de madurez, pueda realizar por sí mismo.

2. Aquellos en que exista conflicto de intereses entre los padres y el hijo".

Además, el artículo $3.1^{\circ}$ de la $L P M\left(L O N^{\circ} 1 / 1982\right)$ dispone que el consentimiento de los menores "deberá prestarse por ellos mismos si sus condiciones de madurez lo permiten, de acuerdo con la legislación civil".

Por último, el Real Decreto № 1.720, de 2007 de 21 de diciembre, dispone que "podrá procederse al tratamiento de los datos de los mayores de catorce años con su consentimiento, salvo en aquellos casos en los que la ley exija para su prestación la asistencia de la patria potestad o tutela. En el caso de menores de 14 años se requerirá el consentimiento de los padres o tutores".

La referencia a la edad de catorce años, que hace el decreto, como destaca Herrán, ha sido fuertemente criticada por cuanto la ley no establece un límite de edad respecto de la capacidad extrapatrimonial. HerRán, "Nueva perspectiva", cit. nota n. 16, p. 470. 
totalidad de las normas que se refieren al suficiente juicio se refieren al deber de oír al menor. Por ello, se podría concluir que las condiciones de madurez exigen un grado de desarrollo mayor, que lo hace un criterio especialmente aplicable respecto del adolescente. A su vez, el suficiente juicio, que se exige para que el menor sea escuchado, se refiere a la capacidad del menor para darse cuenta de lo que se le señala y lo que señala, lo que lo lleva a hacerse entender de una forma clara. Así, en esta etapa o sub-etapa en el desarrollo del menor, no se requiere que éste posea la capacidad para decidir por sí mismo, ya que le falta la madurez para ello. En tal sentido, el suficiente juicio es un grado menor en el desarrollo evolutivo de la persona que las condiciones de madurez. Lo anterior se desprende de las consecuencias que el Derecho otorga a actuar de una u otra manera. El suficiente juicio es solo una herramienta que permite que los padres o el Juez puedan tomar la decisión más acertada respecto del menor, dada su personalidad. En cambio, las condiciones de madurez habilitan al menor a actuar por sí mismo y excluye la representación legal de los padres. Incluso es posible preguntarnos ¿cómo el juez debe valorar la opinión del niño o del adolescente en la etapa previa al reconocimiento de la autonomía específica o general limitada? ${ }^{35}$. Nuevamente para poder responder a esta pregunta el juez deberá recurrir al grado de madurez del niño o del adolescente. El rango de madurez del niño, y especialmente del adolescente, permite darle mayor o menor peso a su opinión, o sea graduarla desde su sola consideración (derecho a ser oído) ${ }^{36}$ hasta su autonomía (capacidad de ejercicio). Así, en los casos en que el

\footnotetext{
${ }^{35}$ La obligación de oír al menor no sólo se plantea respecto de los jueces, sino también respecto de los padres. Así, conforme a una sentencia del Tribunal Supremo español, Sala Civil de fecha 25 de junio de 1994, la obligación de oír al menor no es perentoria para los padres y no constituye causa de privación de la patria potestad. La demandante -una tía de la menor- solicitaba a su vez que se le otorgare la custodia. La referida sentencia resolvió literalmente, lo siguiente: "b) Cuando el artículo 154 determina que 'si los hijos tuvieren suficiente juicio deberán ser oídos siempre antes de adoptar decisiones que les afecten', no impone que hayan de serlo necesariamente en el proceso sobre privación de la patria potestad -como si sucede en el supuesto de desacuerdo en su ejercicio conjunto, artículo 156.2. ${ }^{\circ}$ - sino más bien que los padres habrán de oírles para adoptar las decisiones que les afecten; y c) La invocación en la sentencia impugnada del artículo 171 del CC en su redacción anterior a la Reforma de 13 mayo 1981 está fuera de lugar incluso como elemento interpretativo de la normativa vigente, pero ha de recordarse que el recurso de casación se dirige contra el fallo de la sentencia impugnada y no contra sus razonamientos [Sentencias de 23 marzo 1991 (R] $1991 \backslash 2.435$ ) y 18 febrero 1992 (RJ 1992\1.317)], alguno de los cuales puede ser erróneo o inoperante, como aquí sucede, sin afectar a lo decidido con acierto por el Tribunal de instancia".

${ }^{36}$ En este sentido, la Observación General № 12 (2009), en su párrafo 30 establece: "'[m]adurez' hace referencia a la capacidad de comprender y evaluar las consecuencias de un asunto determinado, por lo que debe tomarse en consideración al determinar la capacidad de cada niño. La madurez es difícil de definir; en el contexto del artículo 12, es la capacidad de un niño para expresar sus opiniones sobre las cuestiones de forma razonable e independiente. Los efectos del asunto en el niño también deben tenerse en consideración. Cuanto mayores sean los efectos del resultado en la vida del niño, más importante será la correcta evaluación de la madurez de ese niño".
} 
menor no posea la madurez suficiente, también nos debemos preguntar ¿a qué criterios puede recurrir el juez para valorar y sopesar la opinión del menor? ${ }^{37}$. A continuación se responderá esta pregunta, respecto del Derecho chileno, estableciendo etapas y sub-etapas con relación a la capacidad extrapatrimonial de los menores.

\section{DistintAS CONSIDERACIONES PARA DETERMINAR}

LA CAPACIDAD EXTRAPATRIMONIAL DE LA INFANCIA Y ADOLESCENCIA

Esta capacidad extrapatrimonial en la infancia y adolescencia se determina conforme a los siguientes criterios: la edad, la madurez y la entidad del derecho afectado, como se verá a continuación. Pero también se debe aplicar el principio de la protección integral del niño y del adolescente, que restringirá o impedirá su autonomía. Como se podrá apreciar estos criterios son totalmente aplicables en Chile.

\section{A. La regla general en materia de capacidad extrapatrimonial, depende de las categorías de niño y adolescente}

La doctrina civil registra algún consenso en torno a que a la capacidad extrapatrimonial no se le aplican las reglas de la representación legal de la patria potestad, por cuanto dichas reglas sólo se refieren a actos patrimoniales ${ }^{38}$. Por ello, para solucionar los problemas de capacidad o incapacidad, se deberá

Observación General № 12 (2009) sobre el derecho del niño a ser escuchado, del Comité de los Derechos del Niño, cit. nota n. 11.

${ }^{37}$ A pesar que la mayoría de la doctrina señala que la opinión del menor no es vinculante para el Juez, postularemos, siguiendo a Rivero Hernández, que la pregunta precedente no tiene una respuesta in abstracto, sino que ello dependerá de cada caso. Pero, a diferencia del referido autor, señalaremos claramente cuáles son estos criterios. Rivero Hernández, Francisco, "La Guarda y Custodia de los Hijos y Derechos de Visita tras las Crisis Matrimonial", en Cevilla Garzón, María Dolores (editora), IV Seminario de Estudios Jurídicos y Criminológicos (la Situación Jurídica de la Mujer en los Supuestos de Crisis Matrimonial), Servicio de Publicaciones de la Universidad de Cádiz, Cádiz, España, 1996, pp. 72-73.

${ }^{38}$ No es del caso reiterar este análisis, pero ello aun estaba claro en el Código de Bello que respecto de las esferas extrapatrimoniales, excluía la representación de los padres y adelantaba la mayoría de edad. Para comprobar esto basta revisar someramente el Código civil respecto de la capacidad para testar, reconocer hijos, casarse, etc. BARCIA, "Informe", pp. 137-158 y "Fallos", pp. 409-422 (ambas cit. nota n. 7). En contra: VARAS BRAUN, Juan Andrés, "Decisiones vitales y representación parental: Fundamento y límites", en Estudios Derecho Civil V, Jornadas Nacionales de Derecho Civil, Concepción, AbeledoPerrot, LegalPublishing, Santiago de Chile, 2009, pp. 337-356. No es del caso referirse a esta discusión -que ya he abordado precedentemente-; pero, a pesar que Varas es exhaustivo al señalar argumentos a favor de lo que denomina "la extensión natural de la representación parental", también señala que "[e] n materia extrapatrimonial, esta autonomía progresiva funciona sin grados o escalas preestablecidas, sino en un continuo evolutivo, cuyo grado concreto de avance, en caso de conflicto, deberá determinar el juez de familia, considerando el grado de madurez del menor y las circunstancias familiares y 
recurrir a un conjunto de reglas, principios y normas propios del Derecho de la Infancia. De ellos es especialmente destacable el principio del ejercicio progresivo de los derechos de la infancia y adolescencia.

Comencemos a analizar las edades relevantes para los efectos de la capacidad extrapatrimonial. A estos efectos, el artículo $16.3^{\circ}$ de la LTF establece que "[p]ara los efectos de esta ley, se considera niño o niña a todo ser humano que no ha cumplido los catorce años y, adolescente, desde los catorce años hasta que cumpla los dieciocho años de edad". Este artículo incorpora a nuestra legislación, a través de la Ley N N 19.968 del 2004, las categorías de niño y adolescente en un sentido que es contrario a lo establecido en el artículo 26 del $C C C^{39}$. Una posible interpretación del artículo $16.3^{\circ}$ es entender que éste ha derogado tácitamente la regulación de los incapaces en razón de la edad. Esta posición se debe desechar por cuanto en la actualidad, y a pesar del tiempo transcurrido desde la promulgación de la norma, nadie ha llegado a plantear dicha solución un tanto extrema. Ello es evidente, ya que una reforma de esta clase afectaría fuertemente las reglas de la capacidad patrimonial, disposiciones que, como se verá, el legislador no tuvo la intención de alterar. Por ello se sostendrá una segunda interpretación, que es la que se plantea en el presente trabajo, conforme a la cual es posible sostener que esta norma establece dos categorías nuevas en nuestro Derecho: la de niño o niña y la de adolescente, pero sólo para los efectos de la capacidad extrapatrimonial. Esta distinción, a pesar de estar establecida en una norma procedimental, tiene una innegable importancia desde una perspectiva netamente civil. Así, por lo demás, se deja de manifiesto en la historia fidedigna de la LTF. Así se desprende del Segundo Informe de la Comisión de Constitución, que incorporó la norma actual, acogiendo la indicación $N^{0} 35$ al Proyecto de $L M C^{40}$. De este modo, en la Comisión,

personales de los padres. En otras palabras, se trata de una evolución continua, y, por lo mismo, sin fronteras graduales predeterminadas". VARAS BRAUN, "Decisiones vitales", cit. nota n. 38, p. 349.

${ }^{39}$ No nos olvidemos que infante o niño para el Código Civil es el menor de siete años; y el menor adulto es el mayor de doce o catorce años, pendiendo si se trata de un menor de sexo femenino o masculino, respectivamente, y menor de dieciocho años.

${ }^{40}$ La indicación de la referencia incorporó el artículo 16 bis al Proyecto de LMC. Dicha Indicación era del siguiente tenor: "Artículo 16 bis. Interés superior del niño, niña o adolescente y derecho a ser oído.

Esta ley tiene por objeto garantizar a todos los niños, niñas y adolescentes que se encuentren en el territorio nacional, el ejercicio y goce pleno y efectivo de sus derechos y garantías.

El interés superior del niño, niña o adolescente, y su derecho a ser oído, son principios rectores que el juez de familia debe tener siempre como consideración principal en la resolución del asunto sometido a su conocimiento.

Para los efectos de esta ley, se considera niño o niña a todo ser humano que no ha cumplido los catorce años, y adolescente desde los catorce años hasta los dieciocho años de edad cumplidos" (lo destacado en cursiva es mío). 
integrada por los senadores Aburto, Chadwick, Espina, Moreno y Silva, se señaló que "[l]os señores representantes del Ejecutivo explicaron que la indicación tiene por objetivo plasmar la garantía del goce pleno de los derechos de los niños, niñas y adolescentes, velando por su interés superior, de acuerdo a los tratados internacionales". Por lo que, en la discusión del Congreso, se deja constancia que se tenía plena consciencia de estar regulando aspectos netamente civiles, mediante una regulación que se podría entender como adjetiva. También podría sostenerse que esta norma se refiere sólo al goce de los derechos; pero ello no tendría demasiado sentido, desde que el goce de los derechos fundamentales estaría dado por ser persona y mediante la referencia al interés superior del niño se aclara que estamos frente a un criterio que determina el ejercicio de los derechos de la infancia. Este, por lo demás, es un criterio fuertemente axiológico por cuanto ha marcado del Derecho de la Infancia en nuestro país y en el Derecho comparado.

Ahora, corresponde determinar la importancia de la distinción entre niños y adolescentes para los efectos de la capacidad. A este respecto, siguiendo la tendencia del Derecho comparado ${ }^{41}$ y la interpretación que se ha hecho de la $C D N^{42}$, es posible sostener que los adolescentes por regla general son plenamente capaces respecto del ejercicio de derechos extrapatrimoniales, salvo

\footnotetext{
${ }^{41}$ La diferenciación entre niño y adolescente es una forma de reconocer la capacidad extrapatrimonial a lo menos de los adolescentes. Esta capacidad estaría reconocida en el ámbito Europeo. Así, algunos autores, como Verhellen, han sostenido que de los artículos 13 y $25.1^{\circ}$ del Convenio Europeo para la Protección de los Derechos Humanos y Las Libertades Fundamentales, de 4 de noviembre de 1950, se desprende dicha habilitación. De esta forma, el artículos 13 del Convenio Europeo establece que "[t]oda persona cuyos derechos y libertades reconocidos en el presente Convenio hayan sido violados, tiene derecho a la concesión de un recurso efectivo ante una instancia nacional..." y agrega el artículo 25, del mismo cuerpo normativo, que: "[l]a Comisión podrá conocer de cualquier demanda dirigida al Secretario General del Consejo de Europa por cualquier persona física...". De esta forma para tener legitimidad activa sólo se requiere ser una persona física. Para Verhellen, del juego de estas dos disposiciones, se desprende la legitimación activa del niño en las causas de derechos humanos y libertades fundamentales.

Además, de las referidas disposiciones, este derecho se desprende de los artículos 14 y $25.1^{\circ}$ de la Convención Europea para la Protección de los Derechos Humanos y las Libertades Fundamentales. Los artículos 14 y $25.1^{\circ}$ establecen que "el goce de los derechos y libertades reconocidos en el presente Convenio ha de ser asegurado sin distinción alguna, especialmente por razones de sexo, raza, color, lengua, religión, opiniones política u otras, origen nacional o social, permanencia a una minoría nacional, fortuna, nacimiento o cualquiera otra situación" y que: "la Comisión podrá conocer de cualquier demanda dirigida al Secretario General del Consejo de Europa por cualquier persona física...". Por otra parte, la Comisión y el Tribunal Europeo han reconocido esta habilitación.
}

${ }^{42} \mathrm{~A}$ pesar que la $C D N$ no establece el derecho a tener legitimidad activa o pasiva, en ejercicio de sus derechos fundamentales, ésta es la tendencia que se ha impuesto por cuanto la Convención establece los derechos mínimos en torno a la infancia. Además, se ha señalado que los derechos fundamentales son derechos en continua evolución. VERHELLEN, E., Convention on the Rights of the Child; Background, Motivation, Strategies, Main Themes, Garant, Verhellen and Garant Publishers N. V., 1994, Belgium, pp. 71-72. 
situaciones excepcionales; y los niños o niñas son incapaces, salvo también casos excepcionales. Los supuestos de excepción naturalmente deben ser calificados por el juez, de acuerdo al principio del interés superior del niño y del adolescente. Una visión más restrictiva de este problema parece tener Cillero cuando señala que la ley será la encargada de implementar los mecanismos a través de los cuales se reconoce la capacidad del niño ${ }^{43}$. En sentido igualmente restrictivo, pero un poco más amplio, se pronuncia Díaz para el cual los menores pueden actuar personalmente, pero asistidos ${ }^{44}$.

A pesar de que autores como Verhellen se inclinan, en el ámbito del Derecho comparado, por el reconocimiento de una capacidad plena para el ejercicio de los derechos del menor, en nuestro ordenamiento jurídico el ámbito de capacidad estaría limitado a la adolescencia, es decir, a los menores de los catorce a los dieciocho años de edad ${ }^{45}$. Estas reglas ya eran reconocidas por nuestro

\footnotetext{
${ }^{43}$ Para el referido autor, la $C D N$ impone la revisión por parte de los distintos países parte, de la implementación de la autonomía del niño, a lo menos en las siguientes materias: "superación del paradigma de la incapacidad; posibilidad de reclamar por sí mismo ante la [j] urisdicción y la [a]dministración por la amenaza o vulneración de sus derechos; posibilidad de oponerse a intervenciones judiciales o administrativas que tendrían como fundamento su bienestar; garantía del derecho a ser oído en juicio y a designar abogado; garantía del derecho a recurrir ante autoridades superiores; libertad de expresión; libertad de conciencia; libertad de asociación y reunión" (lo destacado en cursiva es mío).

En resumidas cuentas el referido autor es de la opinión que las $C D N$ tendría el alcance que se le ha dado en este trabajo; pero Cillero estima que es la ley, y no la interpretación jurídica, la llamada a concretizar la capacidad extrapatrimonial de la infancia y adolescencia. Naturalmente nos inclinamos a favor de una modificación legislativa -esperando que ella sea lo suficientemente inclusiva del Derecho comparado-, pero también es posible entender -como se sostiene en este artículo- que, dada nuestra regulación en materia extrapatrimonial, los menores son totalmente capaces. CiLLERO BRUÑOL, Miguel, "Los derechos del niño: de la proclamación a la protección efectiva", Justicia y Derechos del Niño, 3, 2001, p. 56.

${ }^{44}$ Para el referido autor la actuación asistida del infante se desprende de la propia naturaleza y dignidad del ser humano, pero Díaz entiende por asistencia la actuación a través de la representación en los casos en que el niño no pueda pronunciarse y que corra peligro. A su vez, Valdés trata de delimitar la capacidad de la infancia, en aspectos médicos, desde un prisma constitucional y de los derechos fundamentales. Naturalmente, el esfuerzo es infructuoso si es que no se recurre a los derechos fundamentales de la infancia.

Díaz de VALdés J, José Manuel, "Un marco constitucional para los tratamientos médicos de niños, niñas y adolescentes", Revista Chilena de Derecho, 37, 2, 2010, pp. 283-284.

${ }^{45}$ De este modo, Verhellen señala literalmente que "[t] his movement wants children to have full fundamental civil rights, and to be entitled to exercise these fundamental civil rights automously. The recognition of children's autonomy and right to self-determination is fundamental, as is the acknowledgement of their legal capacity" (este movimiento desea que los menores tengan plenos derechos civiles y sean titulares para ejercer estos derechos fundamentales en forma autónoma). VerHeLlen, Convention on the Rights, cit. nota n. 42, p. 23. El reconocimiento de la autonomía del menor y del derecho a la autodeterminación es fundamental como el reconocimiento de su capacidad legal. Incluso, algunos países como Holanda están estudiando otorgar a los menores el derecho a la eutanasia. Una forma interesante de legislar a este respecto es a través de un Código del Niño. Esta es la tendencia en la mayoría de los países de América Latina, que regulan los Derechos de Niño desde antiguo de
} 
Código y son propias de la codificación. De esta manera, entre nosotros, el menor adulto es capaz respecto de una serie de actos, como para testar (artículos 261 y 1.005 del CCCh) y reconocer a un hijo (artículo 262 del CCCh) o para ser adoptado (artículo $3.2^{\circ}$ de la $L A$ ). Además, los menores adultos, que sean mayores de dieciséis años, pueden contraer matrimonio con el ascenso de las personas a que los obliga la ley. Incluso, nuestro Código Civil establece que los menores adultos, en el campo patrimonial, son capaces respecto de la administración de su peculio profesional (artículos 246 y 439 del CCCh); de la adquisición de la posesión de bienes muebles (artículo $723.2^{\circ}$ del CCCh); de la actuación como mandatario, en cuyo caso los actos que realice en representación de su mandante vincularán sólo a este último (artículo 2.128 del CCCh); de la posibilidad de obligarse por un depósito necesario (artículo 2.238 del CCCh) y de celebrar un contrato de trabajo, aunque con restricciones ${ }^{46}$. En consideración a ello algunos actos requieren de una capacidad para obrar especial.

\section{B. La madurez como criterio basal para determinar la capacidad extrapatrimonial}

La madurez, a pesar de ser el criterio basal para la determinación de la capacidad del niño, exige la intervención del juez, desde que son los padres los que deben velar por el menor. Por ello, en principio, serán los padres los Ilamados a determinar lo que se entiende por condiciones de madurez; pero en

esta forma, es decir, como un todo orgánico. De esta manera, existen Códigos de la Infancia en Brasil (1979), Bolivia (1975), Ecuador (1976), Guatemala (1980), Paraguay (1981) y Perú; Ley Orgánica del Menor en Ecuador Estatuto de Menores en Venezuela (1980) y Estatutos de Minoridad o Código del Niño en la Argentina. En Argentina estos estatutos, de acuerdo a D'Antonio, existen desde hace mucho tiempo en San Juan (1947); Santa Fe (Código del Niño de 1949); Buenos Aires (Ley No 6.661 de 1961), Corrientes (Código del Menor de 1965); Córdoba (Estatuto de Minoridad de 1966); Catamarca (Ley de Protección de Menores de 1982). Pero sin lugar a dudas, la legislación ha tenido mayor influencia y prestigio es el código del Niño de la República Oriental del Uruguay. D'Antonio, Daniel, Derecho de Menores, $3^{a}$ edición, Buenos Aires, Editorial Astrea, 1986, p. 30.

${ }^{46}$ Las distinciones en torno a la edades para trabajar son las siguientes: (a) La mayoría de edad se alcanza a los dieciocho años por regla general (artículo $13.1^{\circ}$ del $C$ del $T$ ). (b) Excepcionalmente, los menores de veintiún años no pueden ser contratados para trabajos mineros subterráneos sin someterse previamente a un examen de aptitud (artículo $14.2^{\circ}$ del $C$ del $T$ ). (c) Los menores de quince años por regla general no pueden trabajar, salvo que se trate de casos debidamente calificados y sean labores artísticas o culturales (artículo 16 del $C$ del $T$ ). (d) Los mayores de quince y menores de dieciséis años. Respecto de estos menores se exige además que hayan cumplido con la obligación escolar y sólo pueden realizar trabajos ligeros, que no perjudiquen su salud y desarrollo, y no impidan su asistencia a la escuela y su participación en programas educativos y de formación (artículos $13.3^{\circ} \mathrm{del} C \mathrm{del} T$ ). (e) Los mayores de quince y menores de dieciocho años. En los dos últimos, el menor debe actuar autorizado por su padre o madre; y a falta de ellos de las siguientes personas, en orden de exclusión decreciente: (i) su abuelo paterno o materno; (ii) guardadores, personas o institución que haya tomado a cargo al menor, y (iii) el respectivo inspector del trabajo (artículo $13.2^{\circ}$ del $C$ del T). Rojas MiÑo, Irene, Manual de Derecho del Trabajo, LexisNexis, Santiago de Chile, 2004, pp. 98-99. 
los casos difíciles el juez será el encargado de determinar dichas condiciones, sobre todo cuando existen diferencias entre el hijo y sus padres. En todo caso, en la segunda parte de este trabajo, se analizará en detalle este criterio.

\section{La entidad del acto como criterio fundamental para determinar la capacidad}

La regla general en torno a la capacidad por edades, por la cual los adolescentes tienen una capacidad limitada y los niños son por regla general incapaces, no es absoluta, presentando importantes excepciones. Ellas se pueden agrupar en torno a la entidad del acto extrapatrimonial sobre la que la eventual capacidad recae. Naturalmente, la madurez es un criterio que está íntimamente relacionado con la entidad del acto que se celebra. La madurez se debe apreciar en concreto. De este modo, no se puede exigir la misma madurez para decidir un cambio de nombre, que para negarse a una transfusión de sangre. A mayor entidad del acto, con relación a los derechos fundamentales más esenciales, o a mayor peligrosidad, mayor será el grado de edad y madurez que el ordenamiento jurídico debe exigir al niño o adolescente para reconocer su autonomía ${ }^{47}$.

\footnotetext{
${ }^{47}$ Así, por ejemplo, en los Estados Unidos de América, no hay un consenso sobre si un incapaz puede no seguir con un tratamiento médico, que de no adoptarse pondrá fin a su vida. La jurisprudencia y doctrina americanas han resuelto dichos casos apreciándolos en forma concreta - "in concreto", diríamos en nuestro Derecho Continental-. Armenteros Chaparro resume los casos de la jurisprudencia americana, distinguiendo las siguientes situaciones:

a) Casos en que el incapaz rechazaría claramente el tratamiento, sin que esta decisión ponga en peligro su vida. Dichos casos son los siguientes: (i) La persona antes de su incapacitación haya rehusado el tratamiento por motivos religiosos. (ii) De los hechos se desprenda una fuerte adhesión a su fe. (iii) No debe existir ninguna evidencia de vacilación en el sujeto.

b) En los otros supuestos menos claros, el Tribunal deberá considerar factores como la fácil identificación de la religión a la cual pertenece el objetor, la fuerza de la convicción que el tratamiento atenta contra sus creencias, extensión de las creencias, etcétera. Además de resolver el problema el tribunal debe determinar desde que momento el incapaz debe ser considerado como tal.

En cuanto a los menores, los Tribunales de Justicia americanos han resuelto que, sobre el interés religioso de los padres, predomina el interés superior del niño. Armenteros Chaparro ha resaltado la tendencia opuesta entre la jurisprudencia americana y la europea en el sentido que la primera tiende a tomar, como un antecedente negativo, en la determinación de la custodia de los niños, la pertenencia a una religión de los padres, que de alguna forma pueda dañar al menor en el futuro. Pero, dicha tendencia contrapuesta obedecería a un cambio reciente en la jurisprudencia europea tendiente a rechazar la discriminación, que se produciría en materia religiosa, respecto de la custodia de los hijos. De esta forma, el citado autor señala textualmente que "[p]or otro lado, en los Estados Unidos la condición de objetor puede constituir un factor de cierto relieve para que los Tribunales decidan atribuir a uno u otro de los progenitores la custodia legal, justamente, la solución contraria a la que parece dominar la orientación del Tribunal Europeo de Derechos Humanos en el reciente caso Hoffmann, en que se declara discriminatoria contra la madre una sentencia de la Corte Suprema de Austria que le retiraba la custodia de los hijos por causa, entre otras razones de sus creencias religiosas como Testigo de Jehová, lo cual implicaría un hipotético riesgo para la vida de los hijos debido al inflexible rechazo de hemoterapia por parte de los miembros de esa secta". Armenteros ChAPARRO, Juan Carlos, Objeción
} 
A pesar de que en Chile no tenemos jurisprudencia sobre órdenes judiciales de transfusión de sangre a menores, a lo menos respecto de los adultos se han acogido recursos de protección que obligan a realizar la transfusión contra las instrucciones dadas en sentido contrario mediante consentimiento informado ${ }^{48}$. Estas órdenes son discutibles respecto de los adultos, pero son totalmente pertinentes respecto de menores, aunque sean adolescentes ${ }^{49}$.

de Conciencia a los Tratamientos Médicos. La Cuestión de la Patria Potestad, Editorial Colex, Madrid, España, 1997, p. 39.

${ }^{48}$ Así lo han resuelto varias sentencias de alzada. De esta forma, el fallo de la CA de Valparaíso, de once de diciembre de dos mil ocho, Rol № 554-2008, resolvió en los siguientes términos: "Primero: Que el presente recurso de protección ha sido interpuesto por Cristián Araya Escobar, Capitán de Navío de Justicia de la Armada de Chile, auditor de la $1^{\text {a }}$ Zona Naval y de la Escuadra, a fin de resguardar el derecho a la vida del paciente don Luis (no se indican apellidos), ante la negativa de éste en orden a que le fuera practicada una transfusión de sangre o de hemoderivados necesarios, según expresa el recurrente, para preservar y, eventualmente, salvar su vida. Segundo: Que, tal como consta del mérito de los antecedentes, efectivamente se encuentra amenazada la integridad física de Luis (no se indican apellidos), bien jurídico que está protegido constitucionalmente según lo previene el artículo 19 № $^{\circ}$ de nuestra Carta Fundamental y que, por expreso mandato contenido en el inciso final del artículo $5^{\circ}$ del mismo cuerpo legal, este Tribunal se encuentra obligado a respetar y preservar. Tercero: Que el imperativo mandato a que se hace referencia en el motivo anterior, no puede ser limitado ni aún por la voluntad de los particulares; en la especie, por la negativa de ésta en orden a realizar la referida transfusión de sangre o de hemoderivados y, muy por el contrario, esta Corte debe precisamente amparar aquellas actuaciones que, como se dijo, tienden a respetar y preservar la vida de las personas, motivo que hace que el presente recurso deba necesariamente ser acogido" (lo indicado entre paréntesis es mío). Ver: http://www.poderjudicial.cl/juris_pjud/muestra_doc.php?docid=60701\&row_id=\&todas_ palabras $=($ testigo $=$ téstigo $=$ testígo $=$ testigó; $d e=$ dé; jehova $=$ jéhova $=$ jehóva $=$ jehová $) \& a l g u n a s \_p a$ labras $=\&$ literal $=\&$ palabra_ $1=\&$ proximidad_ $1=\&$ proximidad_2 $=\&$ proximidad_3 $=\&$ proximidad_ $4=\& p$ roximidad_5=\&proximidad_6=\&palabra_3=\&flag_ninguna=0\&texto=2 [visitado el 12/08/2012]. La CA de Rancagua, mediante una sentencia de 11 de febrero del 2008, en autos Rol № 1.034-2007, se pronuncia en el mismo sentido precedente. En dicha causa, el Servicio de Salud del Libertador General Bernardo O'Higgins recurre contra la decisión de los padres de negarse a una transfusión de sangre indispensable para que su hijo, nacido de forma prematura, pudiese sobrevivir. En este sentido, el fallo es del siguiente tenor: "los médicos del Servicio de Neonatología consideran indispensable una transfusión de sangre, para seguir con su tratamiento y en su caso evitar su muerte, sin embargo, los padres se han opuesto, fundados en que su religión les prohíbe tal práctica médica, conducta que si bien es atendible, vulnera gravemente el derecho a la vida y la integridad física y psíquica del menor, garantizado por la Constitución en el artículo 19 № 1". La sentencia de alzada decide "haciéndose cargo del imperativo Ilamado que realiza la Convención Internacional sobre Derechos del Niño, acoger el recurso intentado, adoptando todas aquellas medidas que importen amparar el interés Superior del niño, representado en este caso por su legítimo derecho a recibir la asistencia médica necesaria y oportuna para seguir con vida y poder, en el futuro, gozar de todos y cada uno de los derechos inherentes a su calidad de persona". Ver: sentencia de la CA de Rancagua, de fecha 11 de febrero de 2008, en autos seguidos entre "Servicio de Salud del Libertador General Bernardo O con Palma y otra", recurso de protección. Cita: MJCH_MJJ22278 | ROL:1034-08, MJJ22278.

${ }^{49}$ A este respeto, en Chile, Lovera señala que "[d]ebemos abrir margen suficiente para que los niños se hagan responsables de sus propias decisiones, incluyendo los errores que de ellas se sigan, pero debemos evitar -al mismo tiempo- la irracionalidad en las mismas. Por supuesto que el criterio sigue siendo uno extremadamente amplio. 


\section{El principio de protección de la infancia y adolescencia como un límite a la capacidad extrapatrimonial}

La protección de la infancia y adolescencia es el principio preponderante en el Derecho de la Infancia. Ello es evidente desde que, en consideración a este principio, el Estado debe actuar como garante de los niños y adolescentes, primando sobre cualquier otra consideración ${ }^{50}$. Así se desprende de los artículos $1.2^{\circ}$ y $5^{\circ}$ y 5 de la $C P E$, de la $C D N$; 54 a 61 de la $L P M$ y $2^{\circ}$ y $3^{\circ}$ de la Ley sobre responsabilidad de los adolescentes por infracciones a la ley penal (Ley No 20.084/2005).

En el campo del Derecho Internacional, y especialmente en el ámbito de la Convención de Derechos del Niño, las normas protectoras del menor se aplican a éste, aun si el menor está emancipado. Por lo que la Convención de Naciones Unidas sobre Derechos del Niño se aplicaría con mayor razón respecto del menor que posea las condiciones de madurez para realizar un acto concreto ${ }^{51}$. En el ámbito español es de destacar la opinión de F. Rivero Hernández, quien, a este respecto, adopta una solución intermedia. El referido autor señala que el menor emancipado "seguirá siendo considerado menor en todo lo que no afecte a la emancipación y sus efectos, es decir, a su no sometimiento a la patria potestad o tutela: espacio residual, pues, muy estrecho para la aplicación a ellos del principio del favor minoris" ${ }^{\prime \prime 2}$. Esta posición es concordante con aquella que señala que los menores alcanzarían su plena capacidad para obrar a los dieciséis años, en el ámbito patrimonial, pero sólo respecto de los actos ordinarios ${ }^{53}$.

Freeman ha sugerido alguna solución: una decisión será manifiestamente irracional -y susceptible de ser revocada por un tribunal- cuando de aceptarse 'socavaría futuras opciones de vida y dañaría intereses de modo irreversible' (cita)" (lo destacado entre paréntesis y cursiva es mío).

LOVERA, "Niño", cit. nota n. 6, p. 18.

${ }^{50}$ Barcia Lehmann, Rodrigo, Fundamentos del Derecho de Familia y de la Infancia, Editorial ThomsonReuters, Santiago, Chile, 2011, №311, p. 383.

${ }^{51}$ De esta manera, Moya Escudero, al referirse a la Convención de Naciones Unidas sobre Derechos del Niño, señala que, conforme a una interpretación finalista del convenio y del Informe de la Comisión Especial dirigida por Lagarde, no puede dejarse fuera del marco de aplicación de éste a los menores emancipados. En consecuencia, la esfera de protección de los derechos se aplica aún, en el caso que los menores tengan capacidad. Así, concuerdo con Moya Escudero cuando señala que "no hay razón para someter una cuestión de derechos humanos al mismo régimen que opera para las cuestiones propias de la capacidad". MOYA EsCUDERO, Mercedes, Aspectos Internacionales del Derecho de Visitas de los Menores Comares, Granada, 1998, pp. 45-48.

52 Rivero, El Interés, cit. nota n. 26, pp. 48- 49.

${ }^{53}$ A esta verdadera emancipación legal se le aplicarían las limitaciones patrimoniales del artículo 323 del Código Civil corregidas.

Linacero de la Fuente, María, Protección jurídica del menor, Editorial Montecorvo S.A., Madrid, España, 2001, pp. 39-44. 
Por otra parte, como ha fallado, reiteradamente la jurisprudencia alemana, los padres pueden perder la patria potestad, en caso de afectar los derechos fundamentales de la infancia, por lo que el principio del interés superior de la infancia, como principio de protección de ésta, está sobre cualquier otra consideración ${ }^{54}$.

\section{Segunda PARTE: \\ ESTRUCTURA DE LAS CONDICIONES DE MADUREZ COMO UN CRITERIO FUNDAMENTAL PARA DETERMINAR LA AUTONOMÍA EN EL EJERCICIO DE LOS DERECHOS DE LA INFANCIA}

En esta parte del trabajo se analizan las condiciones de madurez como criterio fundamental para determinar la capacidad extrapatrimonial, sobre todo respecto de los adolescentes. Ello se debe a que estimamos que en principio los niños son incapaces, salvo excepciones. En la calificación del juez de estas excepciones serán determinantes las condiciones de madurez del infante y del adolescente.

\section{LAS CONDICIONES DE MADUREZ COMO \\ CRITERIO FUNDAMENTAL PARA DETERMINAR LA CAPACIDAD EXTRAPATRIMONIAL DEL NIÑO Y DEL ADOLESCENTE}

A continuación, ya analizado el ámbito de aplicación de las condiciones de madurez dentro de la capacidad extrapatrimonial, se abordarán distintos aspectos a considerar en torno a las condiciones de madurez como criterio fundamental para determinar dicha capacidad. Este es un aspecto fundamental en el presente trabajo, por cuanto, aunque la regla es que los adolescentes sean capaces y los niños sean incapaces, en materia de ejercicio de derechos de la personalidad esta regla no es absoluta y las excepciones a ella se determinan conforme a la condiciones de madurez y los criterios que se han desarrollado precedentemente (apartado 3).

\footnotetext{
${ }^{54}$ Una sentencia de primera instancia de 21 de septiembre del 2009, confirmado por la Corte de Apelaciones de Hamm, resolvió la pérdida del cuidado personal respecto de un padre con relación a sus tres hijos. El padre se había hecho cargo de sus hijos, de 11, 14 y 17 años de edad, dado el fallecimiento de su madre. Sin embargo, el padre no era capaz de educar, ni tratar a sus propios adecuadamente por su carácter irreflexivo y cambiante. Y los niños manifestaban su preferencia por su padrastro y sobre todo por sus abuelos maternos. Los tribunales decidieron poner fin al cuidado personal del padre y otorgarle el cuidado personal a los abuelos. Un segundo caso, menos interesante que el anterior, pone término al cuidado personal de una madre que ha descuidado la educación de sus hijos (sentencia de la Corte de Apelaciones de Brandenburg).

Riveros FerRadA, Carolina, "El rol protector del Estado para con las niñas y los niños frente al derecho de los padres para criarlos y educarlos", en Ruz LárTIGA, Gonzalo (Director científico), Revista Chilena de Derecho de Familia, AbeledoPerrot, LegalPublishing Chile, III, Santiago de Chile, 2010, pp. 123-138.
} 


\section{A. Concepto de condiciones de madurez}

Las "condiciones de madurez" -como regla para determinar la capacidad extrapatrimonial- es lo que se denomina una cláusula general, al igual que el interés superior del niño, o la buena fe en el campo patrimonial. Ello es evidente desde que la madurez se califica "en concreto", o sea, respecto a una circunstancia específica, comparada con criterios objetivos que determinan la madurez.

Para saber lo que se entiende por "condiciones de madurez" se recurrirá al elemento gramatical de interpretación de la ley. Conforme a la definición que da el Diccionario de la Real Academia de la Lengua se entiende por madurez: "f. sazón de los frutos. II 2. fig. Buen juicio o prudencia con que el hombre se gobierna". Por otra parte, el legislador suele emplear esta expresión para referirse a la situación de un menor que, a pesar de estar aún transitando hacia la edad adulta, puede ser tratado como un adulto ${ }^{55}$. En este mismo sentido, la Recomendación del Consejo de Europa № 1.121 (1990) sobre los Derechos del Niño, de 1 de febrero, evidencia que la concepción misma de madurez del menor es evolutiva. Dicha resolución señala textualmente, en su parte considerativa, que "[c] onsiderando que dichos poderes disminuyen (se refiere al poder de los padres) a medida que el niño madura, y que éste es capaz de, progresivamente, ejercer un número creciente de derechos..." (lo destacado entre paréntesis y cursiva es mío); lo que en definitiva refleja que la madurez de los menores está íntimamente ligada con su edad; aunque también lo está con su desarrollo emocional y psicológico ${ }^{56}$. Por otra parte, dentro del Derecho de la Infancia, también es posible vincular la madurez del menor con el deber de educación de los padres. La madurez del niño y del adolescente está íntimamente ligada con dicho deber. En tal sentido, la madurez de éste determinará la educación que le corresponde. Desde un punto de vista netamente jurídico, el proceso de maduración del menor termina con el ejercicio de todos los derechos que

\footnotetext{
${ }^{55}$ En España, Gete-Alonso, et al. señala que el Código civil peninsular utiliza expresiones similares al referirse a la suficiencia de juicio y grado de discernimiento, en los artículos $92.1^{\circ}$ y 156 y 287 del CCE, respectivamente. Gete-Alonso, María del Carmen, Gil Rodríguez, Jacinto, Hualde Sánchez, José Javier y Puig Ferriol, Luis, Manual de Derecho Civil I (Introducción y Derecho de la Persona), Marcial Pons, Madrid, 1995, p. 155.

${ }^{56}$ La edad no es una categoría absoluta en torno a la determinación de la madurez del menor. En este sentido Rivero señala que el "suficiente discernimiento del menor" es una categoría previa a la madurez. De este modo conforme a Rivero "[c]uando hablo de participación del menor en la determinación de su propio interés no quiero decir que siempre sea él quien decide efectivamente acerca de todo lo que le afecta ni que lo haga él solo y directamente, pues de entrada va a depender del grado de madurez del propio menor. Y supuesto un desarrollo psíquico o mental idóneo (discernimiento suficiente)...". RIVERO, El Interés, cit. nota n. 26, p. 297.
} 
le corresponden al individuo ${ }^{57}$. Así, la determinación de la madurez del menor será fundamental para decidir si debe ser considerado capaz; pero, además, si ello no es de esta forma, la madurez es un concepto al que se debe de recurrir para los casos de solucionar conflictos en torno su educación.

\section{B. Condiciones de madurez y derechos de la personalidad}

En España, la mayoría de los autores, como Gitrama y Royo Jara, son partidarios de que el menor actúe personalmente respecto de los derechos fundamentales y de la personalidad ${ }^{58}$. Así también lo ha entendido la Ley Orgánica $N^{0}$ 1/1.982, de 5 de mayo, sobre Protección Civil del Derecho al Honor, a la Intimidad Personal y Familiar y a la Propia Imagen; pero exigiendo a los representantes del menor la obligación de asistencia respecto de éste. Para Royo Jara esta regulación debe entenderse dentro del contexto del Código Civil y los artículos 10, 39 y 49 de la Constitución; por lo que la limitación del ejercicio de los derechos de los menores, sólo cabe con relación a su protección. De este modo, si el menor posee las condiciones de madurez para realizar un acto que implique ejercer un derecho fundamental, no requerirá de representante legal. Sin embargo, ello no será siempre de esta manera y en algunos casos se requerirá que el menor actúe debidamente asesorado o incluso a través de su representante legal ${ }^{59}$.

El ejercicio de esta facultad por parte del menor no es óbice para que los representantes legales no puedan oponerse a la suscripción del acto, en virtud del interés superior del niño (es más, debe considerarse que ellos están obligados a actuar de esta forma para evitar un daño al menor). Lo anterior no supone una inseguridad jurídica, ya que en la mayoría de los casos los terceros podrán contratar con los menores a través de sus representantes legales, pero el problema se plantea cuando los terceros contratan directamente con el menor en

\footnotetext{
${ }^{57}$ Garbarino se refiere a dicho proceso en los siguientes términos: "it is the process of becoming fully human". Garbarino, James, Chapter II, Children's Rights in America: "The Child's Evolving Capacities (Articles 5 and 14 United Nations Convention on the Rights of the Children's)", en PrICE COHEN, Cynthia y Davidson, Howard A. (editors), U. N. Convention on the Rights of the Child Compared with United States Law, American Bar Association, 1990, p. 20.

${ }^{58}$ Royo Jara, José, La Protección del Derecho a la Propia Imagen, Madrid, Colex, 1987, p. 112; HerCe DE LA PRADA, Vicente, El Derecho a la Propia Imagen y su Incidencia en los Medios de Difusión, Bosch editorial, Barcelona, 1994, p. 111.

${ }^{59}$ Esta última solución es aplicable al Derecho chileno, pero es más discutible, respecto al Derecho español. Ello es evidente desde que la autonomía de los adolescentes es evidente en el Derecho español. Así se desprende de lo señalado por Lovera Parmo, cuando señala que "...en ese esquema, niños y niñas reclamando privacidad, libertad de expresión, o reclamando derecho a no someterse a ciertos tratamientos médicos y confidencialidad para consultar sobre métodos de anticoncepción, era impensable". LoverA, "Niño", cit. nota n. 6, p. 15.
} 
atención a sus condiciones de madurez. Esto es una situación excepcional que, en algunos casos, exigirá la notificación a los padres, y que requiere un análisis caso a caso en torno a los efectos del acto ${ }^{60}$. En estos supuestos los representantes legales pueden y deben impugnar el acto, aunque ello también puede estar sujeto a restricciones ${ }^{61}$. El representante legal del menor sólo podrá impugnar el acto si no ha tenido conocimiento de éste o si lo han tenido, por un hecho no imputable no ha podido impugnarlo antes de su ejecución o celebración. El fundamento de la impugnación es la falta de las condiciones de madurez del adolescente o el interés superior de éste. Por supuesto se debe descartar la realización de un acto inmoral, ilícito o abusivo respecto del menor. Sin perjuicio de lo señalado precedentemente, la posición anterior puede ser rebatida, basándose en que el ampliar el ámbito de la capacidad del menor o restringir su incapacidad implica necesariamente disminuir su esfera de protección, ya que los actos que realice bajo dicha esfera no serán impugnables. Por ello, ante el vacío de ley, la calificación del acto debe ser previa o a lo menos debe poder ser objeto de impugnación.

${ }^{60}$ Estas distinciones son especialmente relevantes en torno a los países que admiten el aborto respecto de las adolescentes. En algunos ordenamientos jurídicos se establecen restricciones, como consentimiento informado calificado y notificación a los padres (que puede no llevarse a cabo dependiendo sí el menor recurre ante la Corte). Entre nosotros, a pesar que el aborto no está permitido, la referida discusión se replica respecto de la denominada píldora del día después. El artículo $2.1^{\circ}$ de la Ley № 20.418 sobre Información, Orientación y Prestaciones en Materia de Regulación de la Fertilidad resuelve esta situación en los siguientes términos: "[s] in embargo, en aquellos casos en que el método anticonceptivo de emergencia sea solicitado por una persona menor de catorce años, el funcionario o facultativo que corresponda, sea del sistema público o privado de salud, procederá a la entrega de dicho medicamento, debiendo informar, posteriormente, al padre o madre de la menor o al adulto responsable que la menor señale". La referida normativa entró en vigencia el 2 de febrero del 2010. La oposición de los padres, en el supuesto precedente, no procedería no sólo porque el derecho se radica en la adolescente y no en los padres, sino porque la comunicación es posterior. A su vez, los artículo $6^{\circ}$ y $7^{\circ}$ del Reglamento de la referida ley disponen lo siguiente:

"Artículo 6. En el caso que se trate de un método anticonceptivo de emergencia, que sea solicitado por una persona menor de 14 años, el facultativo o funcionario que corresponda, tanto en el sector público o privado, procederá a la entrega de dicho medicamento, debiendo informar de este hecho con posterioridad, a su padre, madre o adulto responsable que la menor señale, para lo cual consignará los datos que sean precisos para dar cumplimiento a esta obligación.

Artículo 7. Sin perjuicio de lo expuesto en el artículo anterior, toda persona tiene derecho a la confidencialidad y privacidad sobre sus opciones y conductas sexuales, así como sobre los métodos y terapias escogidos para la regulación o planificación de su vida sexual, datos que serán considerados sensibles conforme a la ley No 19.628".

${ }^{61}$ En contra de esta posición, Royo Jara señala que dicha oposición puede producirse por cualquier motivo. Royo, La Protección, cit. nota n. 58, p. 112. Confróntese HerCE, El derecho, cit. nota n. 58, p. 112. Incluso sin adoptar una interpretación a favor de la capacidad del menor, la impugnación a dicho acto puede limitarse por entenderse que opera una autorización tácita a su realización, si el o los representantes legales del menor estaban en conocimiento de la realización de dicho acto y no se opusieron dentro de un término razonable. 
En definitiva, la capacidad extrapatrimonial respecto de adolescentes que cumplan con las condiciones de madurez que exige el acto que se celebra, produce una verdadera extinción parcial de la autoridad parental ${ }^{62}$.

En resumen, de acuerdo a la posición planteada en este trabajo, el adolescente tendría un amplio campo dentro del cual poseería una plena capacidad para obrar o de ejercicio. Esta capacidad se extendería principalmente respecto de los derechos de la personalidad y de acuerdo a las condiciones de madurez, especialmente en las edades más cercanas a la mayoría de edad.

\section{5. ÁMBITO DE APLICACIÓN DE LAS CONDICIONES DE MADUREZ}

El ámbito de aplicación de las condiciones de madurez enfrenta fundamentalmente tres problemas. El primero de ellos es estudiar si las condiciones de madurez pueden aplicarse como una regla general o si, en cambio, sólo es posible recurrir a este criterio en ciertas materias, como es respecto de los derechos de la personalidad. Este análisis lleva a preguntarse si estas condiciones son de aplicación general o, por lo contrario, requieren de norma expresa que permita recurrir a este criterio en supuestos específicos.

El segundo problema a analizar es la relación de las condiciones de madurez y el deber de oír al niño o adolescente. Finalmente, se debe determinar si un menor emancipado, por causa que no fuere la mayoría de edad, puede ser considerado como incapaz en atención a que le falta la "madurez" específica que el acto requiere.

Estos tres problemas se analizaran a continuación.

A. Las condiciones de madurez como uno de los criterios generales para determinar la capacidad del menor

En seguida se analizará si es posible, a falta de norma expresa sobre el régimen de capacidad del menor, entender que el entramado normativo -artículos 26 del CCCh y $16.3^{\circ}$ de la $L T F$ y 5 y 12 de la $C D N-$ nos puede llevar a sostener que la apreciación de "las condiciones de madurez" excede los derechos de la personalidad del menor.

El argumento más fuerte a favor de esta posición es la aplicación mediante la integración del principio del ejercicio progresivo de los derechos del niño y especialmente del adolescente. Del presente trabajo se desprende que este es uno de los principios fundamentales del Derecho de la Infancia y, como tal, se puede aplicar para integrar los vacíos de ley. Así, ante un vacío normativo que no contempla la regulación de la capacidad extrapatrimonial, se debe recurrir

${ }^{62}$ Es parcial porque sólo se refiere a actos concretos. 


\section{al artículo 24 del $C C C h^{63}$. Las reglas de la representación, como se ha señalado en este artículo, son propias de la patria potestad, y no se aplican respecto a la capacidad extrapatrimonial ${ }^{64}$. Ello no es sólo evidente desde que en nuestro}

${ }^{63}$ En este trabajo se sostiene que el principio del ejercicio progresivo de los derechos del niño se aplicaría frente a un vacío normativo en torno a la capacidad extrapatrimonial. Ello en Chile se hace más evidente, por cuanto el Derecho de la Infancia se comporta más como el Derecho Constitucional, que como el Derecho Civil patrimonial, que podríamos denominar como clásico. Esta aclaración es importante por cuanto estos Derechos admitirían la aplicación directa de principios contra norma. En este sentido varios autores han puesto en duda la posición tradicional en virtud de la cual los principios del Derecho se utilizan como regla supletoria de interpretación, por estar considerados como un criterio que se aplica conforme al artículo 24 del Código Civil Chileno, es decir, conforme al espíritu general de la legislación. En este sentido, Guzmán sostiene que si bien el artículo 24 del Código Civil atiende al espíritu general de la legislación chilena, otras normas del Código se refieren al espíritu específico de la ley, como sucede en el artículo 19 del mismo cuerpo legal. Para Guzmán el espíritu general de la legislación no se refiere a los principios generales del Derecho, los cuales son principios y no razones; y sobre el espíritu de la ley se encuentra la equidad natural, que trasciende a una legislación en particular. Para Guzmán si bien Bello utilizó la conjunción " $y$ " es claro que el espíritu debe respetar la equidad natural, por lo que habría un orden de prelación entre ambos criterios en tanto última ratio. No se puede dejar de lado que la doctrina sostiene lo contrario en torno a la relación entre principios de Derecho y espíritu general de la legislación, y ello se sustenta en una razón histórica, que debe revisarse, como lo es la desconfianza del sistema codificado hacia un Derecho que se sustente en principios. Ello sin perjuicio que la posición de Guzmán coincide con el Derecho moderno, que se sustenta precisamente en principios, y ello es más todavía más fácil de argumentar en los Derechos de Familia y de la Infancia por cuanto ellos se estructuran, conforme a las $L M C$ y $L T F$, como Derechos de Principios. Quintana Bravo agrega que en nuestro país ya se puede vislumbrar una teoría general de la interpretación de las normas. En ella se hace indispensable determinar cómo los principios propios de cada rama del Derecho y los generales conviven para determinar el ámbito de aplicación concreto de las normas. Esto no es trivial por cuanto del Derecho moderno, a pesar que se construye sobre normas, ellas son moldeadas por los principios. Para darse cuenta de ello basta analizar el Derecho de Familia, Penal, Constitucional y Laboral, en los cuales los principios moldean las normas. Esta manifestación de la impronta de los principios se concretiza en la máxima que "las normas no se pueden aplicar contra principio". Por ello, cuando el ámbito particular de aplicación de una norma choca con un principio, dicha forma particular de aplicación -dentro de otras posibles- debe desecharse. De este modo, por señalar sólo un ejemplo Atienza y Ruiz, concluyen que los ilícitos pueden ser atípicos en contra de la tesis tradicional, que entiende que el Derecho penal el principio de legalidad se traduce en la máxima "nullum crimen, nulla poena sine lege". Los referidos autores se adhieren a un concepto de ilícito de tipo sistemático que "no denota la entera descripción del delito, sino ciertos aspectos de ella". Los ilícitos atípicos, conforme a esta concepción, serían conductas contrarias a principios. De esta forma, si una norma permite una conducta (se trata de una norma permisiva), pero transgrede un principio, la conducta debe entenderse como prohibida. Los referidos autores nos presentan su teoría de los ilícitos atípicos como una necesidad de coherencia del sistema jurídico, señalando que "se trata de que se produzca un ajuste entre la dimensión directiva y la justificativa del Derecho, entre las reglas y los principios". GuZMán BRITO, Alejandro, "La Historia Dogmática de las Normas sobre Interpretación", en Conferencias y Ponencias Presentadas en el Congreso sobre Interpretación, Integración y Razonamiento Jurídicos. Editorial Jurídica, Santiago, Chile, 1992, pp. 41-87; Quintana Bravo, Fernando, Interpretación y Argumentación Jurídica, Editorial Jurídica, Santiago, Chile 2006, pp. 134-247; AtienZA, Manuel; Ruiz, Juan, Ilícitos Atípicos, Editorial Trotta, 2000, pp. 123-128 y Barcia LeHMAnN, Rodrigo, "Recensión 'llícitos Atípicos", de Atienza, Manuel; Ruzz, Juan, Revista lus et Praxis, 7, 2, 2001, pp. 493-496.

${ }^{64}$ En este sentido, el párrafo 3, del Código Civil chileno, se denomina "de la representación legal de los hijos" y está ubicado en el Título X (que regula la patria potestad), que a su vez está en el Libro I. 
Derecho la patria potestad sólo se refiere a los aspectos patrimoniales, sino también lo es desde que los derechos de la personalidad son indelegables y no admiten representación. De este modo, las condiciones de madurez deben aplicarse como un criterio de determinación de la capacidad, conforme al principio del ejercicio progresivo de los derechos del niño; pero sólo respecto de los derechos no patrimoniales y los patrimoniales que no admitan representación. En el Derecho comparado esta es la tendencia que ha prevalecido, ya sea mediante texto expreso de ley o por aplicación jurisprudencial. De este modo, en España, Albaladejo señalaba que la regla general es la capacidad de obrar del menor. A su vez, agregaba el referido autor ${ }^{65}$, que dicha capacidad se restringe ${ }^{66}$ en virtud de las siguientes causas:

a) Carencia de conocimiento natural: los menores que no tienen la aptitud de entender y querer, claramente no tendrían una madurez adecuada.

b) Materias respecto de las cuales definitivamente le falta independencia y la ley ha excluido su capacidad, v. gr.: por regla general el menor no podrá administrar sus bienes ${ }^{67}$.

A favor de una aplicación general de este criterio como una forma de determinación de la capacidad del adolescente están una serie de normas que se refieren a las condiciones de madurez en varias convenciones internacionales ${ }^{68}$. Así se puede recurrir a la Convención de La Haya sobre Protección

Así, el Código de Bello, como era natural en dicha época, sólo se planteó la representación respecto de los derechos patrimoniales, todo lo demás estaba en un limbo jurídico que debe integrarse conforme al Derecho de la Infancia y Adolescencia.

${ }^{65}$ Albaladejo García, Manuel, Derecho Civil I: Introducción y Parte General, volumen I, Bosch Editor, S.A., Barcelona, 1996, p. 250.

${ }^{66}$ En igual sentido, Moreno Trujillo señala que "cualquier limitación que se imponga, que por lo tanto restrinja esa capacidad de obrar del menor, dentro siempre de los límites que el propio desarrollo personal y de la naturaleza del negocio jurídico que quiera llevar a cabo impongan, habrá de ser interpretado restrictivamente". Moreno TrujlLLo, Eulalia, Actuaciones de Protección del Menor: El Menor en la Legislación Actual, editorial Trigraphis, Granada, España, 1997, p. 53.

${ }^{67}$ Igual sucede con el artículo 7.2 $2^{\circ}$ del Real Decreto № 411/1996, que establece que: "[l]os menores de edad pueden ser donantes de residuos quirúrgicos, de progenitores hematopoyéticos y de médula ósea. En estos dos últimos casos exclusivamente para las situaciones en que exista relación genética entre donante y receptor y siempre con previa autorización de sus padres o tutores (...) En estos casos el donante menor de edad deberá ser oído conforme prevé el artículo 9.1 de la Ley Orgánica 1/1996, de 15 de enero de Protección Jurídica del Menor". De esta opinión también es Moreno Trujillo al indicar que "... [a]sí, es claro el contenido del art. $162.2^{\circ}$ del C.c.: como punto de partida general todo menor es capaz, goza de la suficiente autonomía para realizar aquéllos actos jurídicos que la ley le permita. Solo excepcionalmente, si el grado de madurez no es suficiente, se necesitará la intervención del representante legal". Moreno TrujILlo, "Actuaciones de Protección", cit. nota n. 66, pp. 53 y 54.

${ }^{68} \mathrm{La}$ principal referencia a este criterio se encuentra en los artículos 5 y $12.1^{\circ}$ de la $C D N$, y $13.2^{\circ}$ de la Convención de la Haya sobre los aspectos civiles de la sustracción internacional de menores. De este modo, las normas precedentes son del siguiente tenor: 
de los Niños y la Cooperación en materia de Adopción Internacional, del 29 de mayo de $1993^{69}$. Sin perjuicio de ello, PRICE ha criticado la letra d) del artículo 4 de la Convención por considerarla un avance aparente, ya que las condiciones de madurez se supeditan a la opinión de las autoridades del Estado de origen ${ }^{70}$.

En el Derecho español esta discusión se produce en relación al artículo $162.2^{\circ}, \mathrm{N}^{\circ} 1$ del $C C E^{71}$. Díez-Picazo señala que, conforme al referido numeral, las condiciones de madurez sólo se aplican a los derechos de la personalidad ${ }^{72}$. Así, el referido autor estima que las condiciones de madurez no constituyen

\begin{abstract}
"Artículo 5 de la $C D N$.
Los Estados Partes respetarán las responsabilidades, los derechos y los deberes de los padres o, en su caso, de los miembros de la familia ampliada o de la comunidad, según establezca la costumbre local, de los tutores u otras personas encargadas legalmente del niño de impartirle, en consonancia con la evolución de sus facultades, dirección y orientación apropiadas para que el niño ejerza los derechos reconocidos en la presente Convención.
\end{abstract}

Artículo 12 de la $C D N$.

$1^{\circ}$ Los Estados Partes garantizarán al niño que esté en condiciones de formarse un juicio propio el derecho de expresar su opinión libremente en todos los asuntos que afectan al niño, teniéndose debidamente en cuenta las opiniones del niño, en función de la edad y madurez del niño.

Artículo $13.2^{\circ}$ de la Convención de la Haya sobre los aspectos civiles de la sustracción internacional de menores.

La autoridad judicial o administrativa podrá asimismo negarse a ordenar la restitución del menor si comprueba que el propio menor se opone a la restitución, cuando el menor haya alcanzado una edad y un grado de madurez en que resulte apropiado tener en cuenta sus opiniones".

${ }^{69}$ La referida convención fue promulgada el 4 de octubre de 1999 y en la letra d) de su artículo 4 establece que "[l]as adopciones consideradas por el Convenio sólo pueden tener lugar cuando las Autoridades competentes del Estado de origen: d) Se han asegurado, teniendo en cuenta la edad y el grado de madurez del niño, de que...." y agrega cuatro condiciones que deben de cumplirse (el artículo $21.2^{\circ}$ de dicha Convención establece el mismo criterio).

En España ya la Ley Orgánica 1/1982 de 5 de mayo, sobre Protección Civil del Derecho al Honor, en su artículo $3.1^{\circ}$ consagra esta expresión.

${ }^{70}$ Price se refiere al artículo 5, letra d) del Proyecto precedentemente reproducido. PrICE COHEN, Cynthia, "The Developing Jurisprudence of the Rights of the Child", St. Thomas Law Review, 6, 1993, p. 74.

${ }^{71}$ La norma de la referencia es del siguiente tenor:

"Los padres que ostenten la patria potestad tienen la representación legal de sus hijos menores no emancipados. Se exceptúan:

$1^{\circ}$ Los actos relativos a derechos de la personalidad u otros que el hijo, de acuerdo con las Leyes y con sus condiciones de madurez, pueda realizar por sí mismo.

$2^{\circ}$ Aquellos en que exista conflicto de intereses entre los padres y el hijo.

$3^{\circ}$ Los relativos a bienes que estén excluidos de la administración de los padres.

Para celebrar contratos que obliguen al hijo a realizar prestaciones personales se requiere el previo consentimiento de éste si tuviere suficiente juicio, sin perjuicio de lo establecido en el artículo 158" (lo destacado en cursiva es mío).

${ }^{72}$ Sin perjuicio de lo anterior la doctrina no es pacífica respecto de esta aseveración. Así algunos autores señalan que ciertos actos personalísimos son susceptibles de representación, como los trasplantes u operaciones en general. 
una norma general en materia de capacidad. De esta manera, el principal inconveniente para considerar a las "condiciones de madurez" como el criterio general para la determinación de la capacidad del menor es su extensión sólo a los derechos de la personalidad. Esta línea argumentativa se basa en una norma expresa, y nos lleva a analizar si -tanto respecto del Derecho español, como del chileno- "las condiciones de madurez" se restringen sólo a los derechos de la personalidad. Sin perjuicio de lo anterior, el argumento precedente no es concluyente ni siquiera en España ${ }^{73}$.

También es posible concluir que el establecimiento de las condiciones de madurez, como regla general en materia de capacidad, tiende a configurar la capacidad natural, entendida como la capacidad de entender que el sujeto realmente posee, con la capacidad de obrar, lo que se puede apreciar cada vez de una forma más clara en el Derecho.

En resumen, de lo señalado precedentemente se concluye que entre las edades de los catorce a los dieciocho años-que constituyen la adolescencia-el menor tiene las condiciones de madurez para actuar personalmente, no sólo respecto de los derechos de la personalidad, sino en general, excluyéndose los actos patrimoniales, que se rigen por las reglas de representación de la patria potestad. En todo caso, dichos actos se pueden impugnar acreditándose, mediante informes de especialistas, que el adolecente no posee las condiciones de madurez. A su vez, se puede presumir que los niños, es decir, los menores de catorce años, no tienen la capacidad necesaria para tomar sus propias decisiones, requiriéndose esta vez los informes para acreditar que dichos menores poseen la madurez necesaria para actuar personalmente. En dicho proceso los niños deben ser escuchados. El derecho a ser oído -o el deber de escuchar al menor, desde la perspectiva del sujeto pasivo- es una aplicación el principio del interés del niño desde una vertiente protectora de la infancia, como se aprecia nítidamente en varias sentencias de nuestros tribunales ${ }^{74}$.

\footnotetext{
${ }^{73}$ Así, la aplicación de "las condiciones de madurez" como norma general de capacidad puede producirse por dos vías. Por una vía directa a través de disposiciones que expresamente lo admitan, como el propio artículo $162.2^{\circ}, \mathrm{N}^{\circ} 1$ del $C C E$, los artículos $3.1^{\circ}$ y $3.2^{\circ}$ de la Ley $\mathrm{N}^{\circ} 1 / 1982$, el considerando 10 del preámbulo de la Ley Orgánica sobre Responsabilidad Penal de los Menores, № 5/2000 de 12 de enero, etcétera. Pero, además es posible extender el ámbito de aplicación de las condiciones de madurez a todo el Derecho en forma indirecta, mediante la integración. Así, el referido numeral $1^{\circ}$ del artículo 162 vendría a suplir la falta de una norma general en materia de capacidad del menor. Lo mismo acontece en el Derecho chileno como se podrá apreciar más adelante.

${ }^{74}$ Son varios los fallos que reconocen el deber de oír al menor, que recae sobre los tribunales de justicia. Entre ellos a continuación se señalarán tres a vía simplemente ejemplar.

La CA de Antofagasta, mediante un fallo de diecisiete de agosto de dos mil diez, resolvió respecto de una susceptibilidad de adopción que "[a]así, apareciendo que en todo tipo de procedimientos de familia siempre el menor tiene derecho a ser oído antes de la decisión del tribunal, desde que el tribunal debe tener presente lo dicho como consideración principal del asunto, tratándose de un procedimiento de
} 
Por otra parte, cada una de estas etapas, como se ha señalado precedentemente, estará fuertemente influida por la naturaleza del acto que se celebra, ya que no todos los actos requieren un nivel similar de madurez. A continuación se analizará la madurez como criterio para determinar la autonomía del adolescente y su valoración en el Derecho chileno.

\section{B. La madurez, el deber de oír al niño y al adolescente, y su valoración}

La valoración de la opinión del niño y del adolescente se presenta en el Derecho comparado desde dos perspectivas. Por una parte, en la mayoría de los ordenamientos jurídicos se señala una edad en que es obligatorio, por regla general, escuchar al menor, que va desde los doce a los catorce años ${ }^{75}$. Además, se establece que debe oírse al menor en los casos en que la decisión les afecte. De este modo, a partir de la Reforma al Derecho de Infancia alemán de 1998, es obligatorio escuchar al menor una vez que haya cumplido catorce años o cuando la decisión del juez le afecte. Lo relevante es poder interpretar y valorar dicha opinión ${ }^{76}$. En Chile este criterio se establece expresamente en materia de

susceptibilidad de adopción, ello se ve reforzado desde que la ley de adopción de menores expresamente prescribe que el juez debe tener debidamente en cuenta la opinión del menor para lo cual debe citarlo al tribunal. La redacción de las normas resulta categórica tratándose los menores de estos antecedentes de niños que necesariamente pueden comunicar sus deseos, pensamientos e inquietudes, debió el tribunal citarlos para escucharlos de conformidad a la ley, imperatividad que otorga al trámite el carácter de esencial, pues ciertamente la declaración de los menores constituye una diligencia de prueba, como quiera que el tribunal debe tenerla con especial consideración en cuenta al momento de resolver y, por lo mismo, puede contribuir a determinar al fáctum del juicio y, consecuentemente, su omisión puede producir indefensión, particularmente a los menores". En igual sentido se puede consultar la sentencia de la CA de Familia de Coyhaique, RIT 631-2009, en autos Rol № 15-2010, que falló que "[s]i bien esta obligación de oír al niño o niña, no es equiparable con la de aceptar su deseo, y en este sentido, según se señala en el motivo cuarto del fallo apelado, la menor (se omite dato sensible) manifestó, en un ambiente libre de presiones, su deseo de permanecer con su padre, sin dejar de vincularse con su madre, dicha manifestación, a no dudarlo constituye un factor importante a considerar junto a los demás antecedentes del proceso". A su vez, la CA de San Miguel, en autos Rol № 162 del año 2010, resolvió en su considerando quinto que: “... a mayor abundamiento, el colegio recurrido no acreditó haber tomado declaración o haber entrevistado al menor expulsado en forma previa a adoptar la decisión de desvincularlo definitivamente del referido establecimiento educacional, lo que permite concluir que la medida de expulsión fue tomada sin que él fuera oído por las autoridades de la referida comunidad educativa, siendo insuficiente al efecto la mera constatación de los hechos por una autoridad del establecimiento en la tenencia de carabineros de Santa Rosa de Chena".

Ver en: http://www.unicef.cl/uniceffamilia/2011/09/accion-de-proteccion-a-favor-de-adolescenteexpulsado-de-establecimiento-educacional-debido-a-porte-de-arma-de-fuego-fallo-de-la-c-a-de-sanmiguel-de-fecha-seis-de-septiembre-de-dos-mil-diez/ [visitado el 18/10/2012].

${ }^{75}$ En contra de esta tendencia, como ya se ha visto, está la Observación General № 12 (2009) sobre el derecho del niño a ser escuchado, del Comité de los Derechos del Niño, $51^{\circ}$ período de sesiones, Ginebra, 25 de mayo a 12 de junio de 2009, que sostiene que no debe exigirse ningún límite de edad. Ver: cit. nota n. 11.

${ }^{76}$ De Torres, "Tratamiento", cit. nota n. 19, p. 712. 
adopción. De esta forma, conforme al artículo $3.1^{\circ}$ de la $L A$, "[e]l juez tendrá debidamente en cuenta las opiniones del menor, en función de su edad y madure $z^{\prime \prime}$. Pero la edad es también fundamental desde que, de acuerdo al artículo $3.2^{\circ}$ de la referida ley, la voluntad del menor adulto es decisiva. Así, en caso de negativa del menor adulto para ser adoptado "...el juez dejará constancia de las razones que invoque el menor. Excepcionalmente, por motivos sustentados en el interés superior de aquél, podrá resolver fundadamente que prosiga el respectivo procedimiento". Así, conforme a la norma precedente, siempre lo que debe primar es el interés superior del adolescente.

La $C D N$, en su artículo $12.2^{\circ}$, se refiere al derecho que tiene el niño a ser escuchado en todo procedimiento judicial o administrativo que lo afecte, ya sea directamente o por medio de un representante o de un órgano apropiado. Ello está en consonancia con las normas procedimentales de la legislación chilena $^{77}$. A su vez, los artículos $242.2^{\circ}$, segunda parte, del $C C C h ; 16.1^{\circ}$ y $2^{\circ}$ y $69.1^{\circ}$ de la $L T F, 85.2^{\circ}$ y $3^{\circ}$ de la $L M C$ también consagran este derecho. En este sentido el artículo $242.2^{\circ}$, segunda parte, del CCCh, agrega que el juez, respecto del hijo, "...tendrá debidamente en cuenta sus opiniones, en función de su edad y madurez". A estos mismos criterios recurre el artículo $69.1^{\circ}$ de la $L T F^{7}$. Los preceptos precedentes establecen la edad y madurez como los criterios conforme a los cuales los jueces deben apreciar si toman en consideración las opiniones del menor. En atención a ello la regla general es clara, los jueces deben escuchar al menor, independientemente de su edad. Así, el juez tiene el deber de escuchar al menor "en todos los asuntos que afectan al niño", como se desprende de las normas precedentes y especialmente del artículo 12 de la $C D N$; pero sólo tomará en cuanta dicha opinión en función de su edad y madurez. El juez, a pesar del tenor literal de los artículos $242.2^{\circ}$, segunda parte, del CCCh y $69.1^{\circ}$ de la $L T F$, para evaluar la opinión del menor debe distinguir respecto de sus edades, entre niños y adolescentes.

El tener debidamente en cuenta su opinión -a que se refieren los artículos $242.2^{\circ}$, segunda parte, del CCCh, y $69.1^{\circ}$ de la LTF, como hemos visto-, va

\footnotetext{
${ }^{77}$ La referida disposición es del siguiente tenor:

"Art. 12.

$1^{\circ}$ Los Estados Partes garantizarán al niño que esté en condiciones de formarse un juicio propio el derecho de expresar su opinión libremente en todos los asuntos que afectan al niño, teniéndose debidamente en cuenta las opiniones del niño, en función de la edad y madurez del niño.

$2^{\circ}$ Con tal fin, se dará en particular al niño oportunidad de ser escuchado, en todo procedimiento judicial o administrativo que afecte al niño, ya sea directamente o por medio de un representante o de un órgano apropiado, en consonancia con las normas de procedimiento de la ley nacional".

${ }^{78}$ De este modo el artículo $69.1^{\circ}$ de la LTF establece, respecto de la comparecencia del niño, niña o adolescente en las medidas de protección, que "...el juez tendrá debidamente en cuenta las opiniones de los niños, niñas o adolescentes, considerando su edad y madurez".
} 
desde seguir su opinión en parte, seguirla totalmente e incluso desecharla. Pero en el rechazo de la opinión, sobre todo del adolescente, será determinante su madurez, haciéndose cada vez más difícil que el juez no tome en cuenta su opinión en algún sentido. El artículo 16 de la LTF reafirma esta interpretación, por cuanto la forma en que el juez debe "garantizar a todos los niños, niñas y adolescentes (...) el ejercicio y goce pleno y efectivo de sus derechos y garantías" es precisamente de acuerdo a lo establecido en el inciso $2^{\circ}$ del mismo artículo, es decir, entendiendo que "...el interés superior del niño, niña o adolescente, y su derecho a ser oído, son principios rectores que el juez de familia debe tener siempre como consideración principal en la resolución del asunto sometido a su conocimiento". Por ello, el primer deber del juez es escuchar al menor y el segundo será valorar dicha opinión. La negativa del juez a oír al menor sólo se justifica de producirse algún evento por el cual el menor no está en condiciones de formarse un juicio propio, como se desprende de los artículos $85.2^{\circ}$ y $3^{\circ}$ de la $L M C^{79}$. Ahora bien, excepcionalmente el juez podrá excusarse de escuchar al niño o el adolescente en casos en que un informe psicológico avale su inconveniencia o si es imposible por su edad que el menor manifieste una opinión ${ }^{80}$. A

\footnotetext{
${ }^{79}$ Un criterio que complementa a la madurez es la determinación de la falta del "juicio suficiente". Este criterio puede servir para decidir no oír al menor; pero al ser un grado inferior en el desarrollo del menor con relación a la madurez, dicho criterio es más laxo en torno a las edades. De esta manera, el menor debe ser oído si tiene a lo menos doce o catorce años, en casi cualquier circunstancia, y en los casos que fuere menor, de dicha edad, se debe comprobar que no tiene el suficiente juicio para no ser escuchado.

${ }^{80}$ En este sentido, una sentencia de la CA de San Miguel, de fecha 7 de diciembre del 2011, en sus considerandos tercero y cuarto resuelve que "el examen de los antecedentes revela que, efectivamente, el menor J.L.S., de actuales 9 años de edad, no fue escuchado durante el juicio, desatendiéndose el mandato contenido en el artículo 16 de la Ley № 19. 968, en cuanto establece el derecho del niño a ser oído como uno de los principios rectores que el juez de familia debe tener siempre como consideración principal en la resolución del asunto sometido a su conocimiento. Por su parte, la Convención sobre los derechos del Niño, impone el mismo deber al consagrar en su artículo 12 que deberá garantizarse al niño que esté en condiciones de formarse un juicio propio, expresar libremente su opinión, para lo cual se le dará la oportunidad de ser escuchado en todo procedimiento judicial o administrativo que lo afecte. CUARTO: Que en esta causa, dar cumplimiento a tal normativa era especialmente relevante, si se considera que se trataba de disponer la forma cómo debía generarse un régimen comunicacional con un padre ausente por muchos años, todo lo cual provoca en el menor un importante grado de ansiedad, según se deja constancia en uno los informes periciales que la sentenciadora tuvo como elementos de prueba. Escuchar al menor en una materia que es de su directa y total incumbencia, era también posible si se considera que la pericia psicológica da cuenta que tiene un desarrollo físico y maduracional propio del ciclo vital en que se encuentra, su desarrollo de lenguaje es apropiado y tiene la capacidad de comprender y expresar ideas de forma clara y fluida. Se daban así las condiciones necesarias para cumplir con tal esencial diligencia, cuyo resultado es determinante al momento de decidir si el derecho que el padre quiere ejercitar debe prevaler sobre el interés superior del menor, que según el artículo $3^{\circ}$ de la Convención ya citada, debe tenerse en cuenta como una consideración primordial. Al no haberse procedido de la manera dicha, se ha faltado a una diligencia, cuyo carácter esencial es incuestionable, siendo la única forma de reparar tal omisión la anulación de la sentencia y
} 
su vez, a pesar de que el adolescente dé su opinión y aun si posee la madurez necesaria para ser tomado en consideración, excepcionalmente el juez podrá no darle valor alguno a ella si ésta atenta contra el propio interés del menor, pero en un sentido que no es aceptable por el ordenamiento jurídico.

En resumen, las condiciones de madurez se refieren a aspectos concretos. Ellas determinan desde el deber de escuchar al menor hasta el reconocimiento de su capacidad; pero, conforme lo hasta acá analizado, no se podría concluir que un menor posee unas condiciones de madurez que dan lugar a su emancipación.

\section{La inmadurez como causa incapacitante}

Un aspecto no desarrollado por la dogmática es determinar si es posible considerar a la inmadurez como causa incapacitante del menor, estando vivos sus padres. En este sentido, se debe estudiar si "las condiciones de madurez" pueden ser utilizadas como una restricción a la capacidad del menor. Ello es relevante, sobre todo si, como se ha hecho en este trabajo, se considera que los adolescentes son, por regla general, capaces para ejercer sus derechos extrapatrimoniales. Es verdad que el problema es más teórico que real por cuanto la capacidad puede ser valorada por los jueces ante la oposición de ambos padres o de uno de ellos. Al respecto, parece ser claro que no podría sostenerse que el menor no puede celebrar actos específicos respecto de los que tendrían capacidad -por ejemplo, para testar sí es menor adulto-, porque no tiene las condiciones de madurez. Ello es evidente desde que existe una norma legal habilitante para ello en nuestro Derecho ${ }^{81}$. Como es natural, un alto grado de inmadurez puede llevar a que una persona sea incapacitada de acuerdo a dicho grado, por demencia o prodigalidad.

Finalmente, la inmadurez de un menor emancipado no es una causa de inhabilitación, salvo que concurra con otras circunstancias, como prodigalidad

del juicio que le sirve de antecedente, por lo que el recurso de casación, sobre la base de esta causal, será acogido".

La sentencia evidencia que para la Corte es un trámite esencial del proceso el que se escuche al menor. CA San Miguel, 7 de diciembre de 2011, considerandos $3^{\circ}-4^{\circ}$, Rol № $773-2011$. Cita: MJCH_MJJ36106.

${ }^{81}$ Pero, el concepto de madurez se amplía dentro del Derecho comparado y alcanza incluso a los mayores de edad. Ello sucede a través del alcance que le ha dado la doctrina al autogobierno, como causa de incapacitación en el artículo 200 del CCE. De esta forma, por ejemplo Ramos Chaparro señala que "[p]ensamos que el autogobierno personal es, de suyo, un concepto psicológico que ha dado de sí una noción o categoría jurídica al erigirse en requisito de los actos y negocios, adoptando la 'forma' de concepto jurídico indeterminado para aludir al modelo o canon jurídico-social de la normalidad y madurez mentales, caracterizado negativa y cuantitativamente por la ausencia de graves cuadros 0 síntomas psicopatológicos en la persona". Ramos Chaparro, Enrique, "Enfermedad Física, Autogobierno e Incapacitación", Poder Judicial, 34, 1994, p. 405. 
u otra forma de incapacitación; o que el principio de la protección del menor lleve a considerar su inmadurez como criterio conducente a desechar la emancipación de un menor de edad.

\section{APRECIACIÓN DE LAS CONDICIONES DE MADUREZ}

Como este tema no ha sido desarrollado en el Derecho chileno, me referiré someramente a los principales criterios conforme a los cuales se configuran las condiciones de madurez en el Derecho comparado.

Lo primero que se debe recalcar es que en algunos campos del Derecho la apreciación de las condiciones de madurez del menor es más difícil que en otros. De acuerdo a Garbarino, será relevante en el proceso de madurez del niño, el desarrollo de sus capacidades cognoscitivas y su nivel de inteligencia $^{82}$. Pero la medición de la inteligencia es compleja. Ello se debe a que dicho concepto es multidimensional, en el sentido que la madurez comprende diferentes habilidades y, por ello, se deberá recurrir para su determinación a exámenes técnicos o de especialistas. De este modo, en la determinación de las condiciones de madurez no sólo tendrá mucha importancia la forma en que se evalúa la prueba, sino que también las instrucciones que los tribunales dan a los especialistas en torno a sus informes ${ }^{83}$.

${ }^{82}$ Garbarino, J., "The Child's Evolving Capacities (Articles 5 and 14 United Nations Convention on the Rights of the Children's)", Chapter II, Children's Rights in America: U. N. Convention on the Rights of the Child Compared with United States Law, edited by Cynthia Price Cohen \& Howard A. Davidson, American Bar Association, 1990, p. 22

${ }^{83}$ Tal vez uno de los campos del Derecho en el que es más difícil fijar el alcance de la cognición del menor son los abusos sexuales. Ello no sólo se debe a que, en la mayoría de los casos, no existen indicios físicos del abuso, sino también a la dificultad de determinar qué es realidad y qué es ficción para un niño. De esta forma, de acuerdo a M. Diges Junco y M. L. Alonso-Quecury, los niños no declaran respecto de estas situaciones, y sus reacciones son muy variadas y van desde el movimiento de la cabeza a la imposibilidad de declaración. Así, respecto de la manifestación de su voluntad, en la medida que los menores superan edades muy tempranas, como los cuatro o cinco años se hace muy difícil el diferenciar que es ficción y que es realidad. En esta materia, se pueden producir las siguientes tres situaciones de hecho. La primera es respecto de los menores que no manifiestan su voluntad de forma alguna, principalmente por su corta edad, me refiero a los menores que ni siquiera pueden hablar. Respecto de ellos en materia penal sólo se podrá acreditar la existencia del hecho punible mediante pruebas directas. Una segunda situación se refiere a los menores que pueden manifestar su voluntad, pero es difícil diferenciar la realidad de la ficción. Y, por último, existe un campo intermedio respecto de menores que manifiestan su voluntad, pero dada su corta edad no pueden dar detalles de lo que les sucede. De acuerdo a Diges Junco y Alonso-Quecury, respecto de estos menores sólo será posible que los síntomas que se presentan, como pesadillas, pérdida de apetito, síntomas de desamparo, secreto, etcétera sean evaluados por especialistas y dichos informes sean evaluados por los tribunales a través de las reglas de la sana crítica o como una prueba de presunciones. De esta forma, en los países del Common Law es admisible la declaración de psicólogos o psiquiatras para que testifiquen sobre la existencia de abusos sexuales concretos. Diges Junco, M. A. y QueCutr, M. L., "El Psicólogo Forense Experimental y la Evaluación de Credibilidad de las Declaraciones en los Casos de Abuso Sexual a Menores", Revista del Poder Judicial, 35, 1994, p. 48. 


\title{
A continuación se desarrollará un breve resumen de las posiciones más destacadas con relación a la determinación de las condiciones de madurez.
}

\section{A. Determinación de las condiciones de madurez por los padres}

\author{
Los derechos y facultades de los padres con relación a los hijos en el campo \\ extrapatrimonial se desprenden de la autoridad parental (conforme a nuestra \\ actual legislación $)^{84-85}$ y sobre todo de la corresponsabilidad ${ }^{86}$. Por ello ambos
}

En España, los tribunales deciden sobre la procedencia de estas pericias, aunque el artículo 456 de la Ley de Enjuiciamiento Criminal no especifica los conocimientos que deba tener el referido perito. Lo que los expertos analizan en estos supuestos son la capacidad volitiva del menor. Pero respecto al ámbito de extensión del informe de peritos existen dos posiciones. En los países de influencia anglosajona, el informe de peritos explica si los síntomas que presenta el menor son reveladores del abuso sexual; en cambio, de acuerdo a los países que siguen la tradición germánica, el especialista emite un informe general sobre la credibilidad de la declaración del menor. Los profesores U. Undeutsch de Alemania y A. Trankell de Suecia, han elaborado un complejo sistema de evaluación de credibilidad de testigos menores en materia de abusos sexuales que se ha seguido por algunos países, como España -este sistema se aplica en Madrid y Tenerife-, algunos estados de los Estados Unidos de América y Japón. Este sistema de evaluación es la manifestación de los criterios precedentemente señalados, más unos criterios que se pueden calificar como negativos. Dentro de los primeros están, el que los contenidos de la declaración se sitúe en lugares concretos, y en un momento determinado. La manifestación especial de criterios anteriores se refiere a cuestiones más específicas y, finalmente, los criterios negativos que tienden a establecer indicadores de baja credibilidad. Además Undeutsch agrega los siguientes cuatro factores a saber: (i) la intensidad con que ha sido pronunciado cada uno de los criterios durante la entrevista; (ii) El número de detalles que aparecen en la declaración; (iii) La capacidad de la persona que declara, y (iv) Las características del suceso. Finalmente, el informe del psicólogo, tras el presente análisis, elegirá entre cinco opciones que van desde creíble a increíble. DıGES JUNCO y QUECUTY, "EI Psicólogo", cit. nota n. 83, p. 56.

${ }^{84}$ La autoridad de los padres o parental está regulada en el Título IX denominado "De los Derechos y Obligaciones entre los Padres y los Hijos" del Libro I del Código Civil (artículos 222 a 242), normas que también se refieren al cuidado personal. La doctrina suele definir a la autoridad parental como el conjunto de facultades y deberes, por una parte, y derechos y obligaciones, por la otra, que se producen entre padres e hijo y relativos a la persona de este último, y no a los aspectos patrimoniales de la filiación que se regulan en la patria potestad. Así, Ramos Pazos señala que la autoridad parental "[t]radicionalmente ha sido definida como el conjunto de derechos y obligaciones de contenido eminentemente moral, existente entre padres e hijos". Ramos Pazos, René, Derecho de Familia, tomo II, $7^{\text {a }}$ edición actualizada, Editorial Jurídica, Santiago, Chile, 2007, № 606, p. 458.

${ }^{85}$ Como he sostenido en otro trabajo sobre la autoridad parental, contra la tendencia mayoritaria, estimo que ella es conjunta por cuanto los deberes de alimentos y educación, naturalmente lo son. De este modo, sí dichos deberes son conjuntos, debe entenderse que la autoridad parental en su manifestación de facultad también es conjunta. Ello a diferencia del cuidado personal que es indistinto, conforme a lo establecido en el artículo $225.3^{\circ}$ del CCCh. Lo anterior a pesar de lo señalado en la discusión de la $L F$ y el reciente fallo del TC, Rol № 2.306-2012, de treinta de mayo de dos mil trece, que declaró la inconstitucionalidad parcial de la norma precedente (ver: http://www.tribunalconstitucional.cl/wp/ sentencias/busqueda-avanzada [visitado el 25/03/2013]) Historia de la LF, volumen No IV, p. 2.741. BARCIA, "Fundamentos", cit. nota n. 50, pp. 468-470.

${ }^{86}$ La Reforma introducida al cuidado personal, por la Ley № 20.680 del 2013, viene a ratificar estas conclusiones. Así, el nuevo artículo 244 del CCCh establece una corresponsabilidad conjunta de los 
padres de forma conjunta pueden autorizar a sus hijos a actuar respecto de los derechos extrapatrimoniales, pero sujetos al principio del interés superior del niño como ejercicio progresivo de los derechos de la infancia y como protección de la infancia y adolescencia. Además de las normas pertinentes del $C C C h$, avala esta posición el artículo 18 de la CDN. Así, conforme a la referida norma: "[I]os Estados Partes pondrán el máximo empeño en garantizar el reconocimiento del principio de que ambos padres tienen obligaciones comunes en lo que respecta a la crianza y desarrollo del niño. Incumbirá a los padres o, en su caso, a los representantes legales la responsabilidad primordial de la crianza y el desarrollo del niño. Su preocupación fundamental será el interés superior del niño".

Sin perjuicio que los padres naturalmente son los llamados a calificar las condiciones de madurez - por cuanto ellos son los que mejor conocen a sus hijos $^{87}$-, dicho derecho no es exclusivo de éstos. De este modo, si bien es indudable que los padres pueden otorgar un grado de autonomía al menor, en los casos que consideren que éste posee las "condiciones de madurez"; en las situaciones de conflicto debe ser posible recurrir a una forma más objetiva de determinación ${ }^{88}$. Incluso puede ser que los padres no estén de acuerdo, en cuyo caso el ordenamiento jurídico debería establecer criterios claros que determinen las condiciones de madurez que el acto requiere. Por otra parte, la especificación de la capacidad exclusivamente por los padres haría imposible crear un concepto de condiciones de madurez que tenga un sustento objetivo, ya que los padres arbitrariamente apreciarían si su hijo posee dichas condiciones. Tampoco sería posible comparar la situación de un menor con la de otros menores. Así, unos padres podrían considerar maduro a un menor, en un estado de desarrollo similar a otro, al que sus padres no consideren como tal.

\footnotetext{
padres, que comprende la crianza y educación del hijo, y opera aun en el caso en que éstos estén separados. El nuevo artículo 224 del CCCh dispone que "[t]oca de consuno a los padres, o al padre o madre sobreviviente, el cuidado personal de sus hijos. Éste se basará en el principio de corresponsabilidad, en virtud del cual ambos padres, vivan juntos o separados, participarán en forma activa, equitativa y permanente en la crianza y educación de sus hijos".

${ }^{87}$ RoYo, La protección, cit. nota n. 58, p. 112; HeRCE, El derecho, cit. nota n. 58, p. 67; RAMOs, "Niños y jóvenes", cit. nota n. 4, p. 185.

La calidad de impúber, en el Derecho romano, era determinada por los padres. En la época de Justiniano se modificó este criterio. Al respecto los sabinianos señalaron que la pubertad debía determinarse caso a caso, mediante la inspectio corporis. Pero, Justiniano adoptaría, por razones de pudictia, la opinión de los proculeyos. Para éstos se debe distinguir de acuerdo a la edad de los hombres y mujeres, entre catorce y dos años, respectivamente. Iglesias-Redondo, Juan, Derecho Romano, Ariel Derecho, Barcelona, 1999, p. 93; Schulz, Fritz, Derecho Romano Clásico, Bosch, Barcelona, 1960, p. 167; D'ORS, Álvaro, Derecho Privado Romano, Ediciones Universidad de Navarra, S. A., Pamplona, 1991, pp. 350 y 351.

${ }^{88}$ Así, en los casos que los padres estimen que el menor puede tomar sus propias decisiones se produciría una verdadera ampliación de la capacidad de los menores o una emancipación específica, dependiendo de aquéllos.
} 
Varas - a pesar que no desconoce formalmente el principio del ejercicio progresivo de los derechos de la infancia- otorga a los padres un derecho preferente para decidir respecto del menor en el ámbito de la capacidad extrapatrimonial. Sin embargo, estima que el juez puede calificar la decisión de los padres como "una opción ética y jurídicamente admisible dados los principios y normas constitucionales en juego, en el contexto de una democracia que debe tolerar (y seguramente fomentar, pero eso no es materia de este trabajo) la diversidad de opciones o modos de vivir una vida buena" 89 .

En resumen, excluyendo la opinión de Varas, las condiciones de madurez, conforme a esta interpretación -por la que los padres exclusivamente determinan las condiciones de madurez-, tendría un alcance bastante limitado. Sin perjuicio de lo anterior, no se puede dejar de lado que los padres, por regla general, serán los que determinen si sus hijos tienen el estado de madurez suficiente que el acto requiere. Una autorización general de los padres, a este respecto, puede concebirse como adecuada sólo si no impide que los padres o un tercero pueda intervenir en casos concretos, conforme al principio de protección de la infancia y adolescencia ${ }^{90}$. Pero la determinación de las condiciones de madurez por parte del juez es relevante respecto de terceros, sobre todo con relación a los actos que tienen una trascendencia tal que no basta la sola autorización o representación legal de los padres, y aun respecto de los padres en caso que ellos no estén de acuerdo.

\section{B. Determinación de las condiciones de madurez conforme al Derecho de la Infancia}

No es del caso reiterar las posiciones dogmáticas conforme a las cuales, recurriendo al artículo $5^{\circ}$ de la $C P E$, es posible interpretar e incluso integrar las normas de nuestro Derecho acorde a las convenciones y los tratados internacionales, sobre todo de derechos humanos, como sucede respecto

\footnotetext{
${ }^{89}$ El autor además agrega que los que el juez debe evaluar es una suerte de contraposición de decisiones entre los padres con relación a tercero, entre los propios padres o de ellos con relación al hijo. VARAS BRAUn, Juan Andrés, "Decisiones vitales y representación parental: Fundamento y límites", en Estudios Derecho Civil V, Jornadas Nacionales de Derecho Civil, Concepción, AbeledoPerrot, LegalPublishing, Santiago de Chile, 2009, pp. 350-356.

${ }^{90}$ La determinación de la delegación de la representación de los padres al hijo creemos que cae dentro de la autoridad parental y la corresponsabilidad y no dentro del cuidado personal, por lo que se requerirá la voluntad de ambos padres. La posibilidad de otorgar una autorización amplia de actuación por parte de los padres, dependerá de la calidad de niño y adolescente del hijo, en un sentido muy similar entre la distinción entre menor adulto e impúber del Derecho Patrimonial. BARCIA, "Fundamentos", cit. nota n. 50, pp. 468-470.
} 
de la $C D N^{91}$. Ello es evidente desde que para presentar a la madurez como un criterio basal, para determinar la capacidad extrapatrimonial, basta con recurrir a la $C D N$.

La $C D N$ determina la capacidad extrapatrimonial en torno a las edades, pero relacionándolas con la madurez. Así, en el preámbulo de la Convención se establece que "el niño, por su falta de madurez física y mental, necesita protección y cuidado especiales, incluso la debida protección legal, tanto antes como después del nacimiento", y agrega, el artículo $12.1^{\circ}$ de la misma Convención, que "[I]os Estados Partes garantizarán al niño que esté en condiciones de formarse un juicio propio el derecho de expresar su opinión libremente en todos los asuntos que afectan al niño, teniéndose debidamente en cuenta las opiniones del niño, en función de la edad y madurez del niño" (la negrita es mía).

La CDN evidencia la relación entre edad y madurez, lo que unido al ejercicio de ciertos derechos fundamentales de la niñez -que son reconocidos como autónomos, por cuanto no admiten representación-, nos llevan necesariamente a la conclusión de que los niños y adolescentes tienen un rango importante de autonomía, en el ejercicio de sus derechos fundamentales. De este modo sucede respecto al derecho al nombre, derecho a saber su origen biológico (acceso a archivos), derecho a la identidad -este derecho está protegido principalmente por acciones de filiación- ${ }^{92}$, derecho a la libertad personal con una fuerte limitación a la libertad sexual; derecho a la libertad religiosa, de conciencia, ideología y de culto; libertad de expresión e información y derecho al honor, la intimidad y a la propia imagen, etc. Además, la norma, a pesar de ser consensuada por varios países, es imperativa desde que establece "...teniéndose debidamente en cuenta las opiniones del niño". Si esto lo unimos a que el CDN es una convención de mínimos, el juez debe esforzarse por darle un sentido específico a la opinión del niño.

\footnotetext{
${ }^{91}$ Una de las características relevantes de esta Convención es que los Estados Partes se comprometen a su implementación progresiva de acuerdo a su artículo 4 y a dar cuenta de los avances que se realizan en tal sentido. Esta implementación progresiva si bien en un principio de interpretó como que no era necesario implementar todos los derechos de la Convención en un solo instante, con posterioridad se entendió que el establecimiento de los distintos derechos de la infancia son sólo un punto de partida.

${ }^{92}$ Con Riveros estimamos que existe una acción de conocimiento de origen biológico que se debe analizar a raíz de la adopción y los Tratamientos de Reproducción Asistida. Esta acción es constitucional y no da lugar a un vínculo de filiación. Barcia LeHmann, Rodrigo y Riveros FerRada, Carolina, "El Derecho al Conocimiento del Origen Biológico como un Derecho Fundamental de Naturaleza Civil-Constitucional Derivado del Derecho a la Identidad y de la Dignidad Humana", en Gómez DE LA TORRE (Directora), Las Técnicas de Reproducción Humana Asistida. Desafíos del Siglo XXI: Una mirada Transdisciplinaria, AbeledoPerrot, LegalPublishing Chile y Thomson Reuters, Escuela de Posgrado, U. de Chile, Santiago, Chile, 2013, pp. 189-221.
} 
Por otra parte, la legislación chilena tangencialmente se refiere a la madurez en términos muy parecidos a la $C D N$. En este sentido se expresan los artículos $242.2^{\circ}$ del $C C C h$, y $85.2^{\circ}$ de la $L M C^{93}$.

El artículo $242.2^{\circ}$ del CCCh es especialmente relevante por cuanto el cierra el Título VIII, del Libro I, que regula "...los derechos y obligaciones entre los padres y los hijos".

En el Derecho comparado también es posible apreciar esta tendencia a favor de las condiciones de madurez como criterio para determinar la capacidad extrapatrimonial. Así, en España este criterio se desprende de la normativa general del Código Civil. De este modo, la Instrucción del Ministerio de Justicia № 2/1993 de 15 de marzo de 1993, sobre Protección de Menores aplica este criterio $^{94}$. El referido Informe señala que la fórmula legal empleada por la Ley de Protección Jurídica del Menor se halla en armonía con el régimen general que el artículo $162.1^{\circ}$ del Código Civil establece respecto de la representación legal de los hijos. Pero respecto de la posesión de cualificadas "condiciones de madurez", el Informe sugiere tomar como referencia el patrón normativo de diversos preceptos del Código Civil que, en otras materias, permiten al menor realizar determinados negocios jurídicos a partir de cierta edad -14 años-, o exigen su audiencia si fuera mayor de 12 años o tuviere suficiente juicio (cfr. artículos $663,177.3^{\circ}, 156$ y 92 del $\left.C C E\right)^{95}$.

\footnotetext{
${ }^{93}$ De este modo, los artículos $242.2^{\circ}$ del CCCh, y $85.2^{\circ}$ de la $L M C$ disponen lo siguiente:

"Artículo $242.2^{\circ}$ del CCCh. En todo caso, para adoptar sus resoluciones el juez atenderá, como consideración primordial, al interés superior del hijo, y tendrá debidamente en cuenta sus opiniones, en función de su edad y madurez.

Artículo $85.2^{\circ}$ de la $L M C$. Cuando existieren menores de edad comprometidos, el juez deberá considerar especialmente el interés superior del niño, y oirá a aquél que esté en condiciones de formarse un juicio propio, teniéndose debidamente en cuenta sus opiniones, en función de su edad y madurez, al resolver todos los asuntos relacionados con su persona o sus bienes".
}

${ }^{94}$ Dicho informe, después de señalar el especial interés que tienen los Sres. Fiscales en el contenido de los artículos $3.1^{\circ}$ y 2 de la $L O N^{\circ} 1 / 1982$, se refiere al régimen jurídico observable en aquellos casos en que el titular de los derechos que pueden ser objeto de menoscabo es un menor o un incapaz. De esta forma señala literalmente, lo siguiente: "1. El consentimiento de los menores e incapaces deberá prestarse por ellos mismos si sus condiciones de madurez lo permiten, de acuerdo con la legislación civil. 2. En los restantes casos, el consentimiento habrá de otorgarse mediante escrito por su representante legal, quien estará obligado a poner en conocimiento previo del Ministerio Fiscal el consentimiento proyectado. Si en el plazo de ocho días el Ministerio Fiscal se opusiere, resolverá el Juez".

${ }^{95} \mathrm{El}$ aludido instructivo analiza el conflicto entre la intimidad del menor y el derecho de información y agrega: "Sin embargo, constituye preferente preocupación de la Fiscalía General, no ya el prefijar topes convencionales que actúen de referente en los supuestos ordinarios, sino impedir que el impacto psícoemocional que pueda sufrir un menor -incluso, de suficiente madurez-, en ciertos casos especiales, sea empleado para la obtención de un consentimiento irreflexivo o que esté motivado por la momentánea, artificiosa y efímera atracción hacia una popularidad asentada exclusivamente en el insano fisgoneo que generan algunos sucesos delictivos". 


\section{Determinación de las condiciones de madurez conforme a criterios técnicos}

La determinación de la madurez del menor será un aspecto técnico y, como tal, el Juez deberá solicitar los informes psicológicos o médicos, que le ayuden a determinar la madurez del menor. Garbarino señala que uno de los métodos de evaluación de la inteligencia más acertado es el desarrollado por Sternberg. Dicho análisis toma en consideración los siguientes aspectos, en relación al menor:

a) Sus facultades analíticas (ellas serán evaluadas conforme a un test de "raw analytical power").

b) Su experiencia ("experiential test"). A su vez, la experiencia comprendería el poder apreciar lo que es relevante de una situación compleja ("selective encoding"); poder determinar qué es lo relevante de un problema ("selective combinations") y tener la capacidad de detectar la analogía entre metas o situaciones diferentes o no conectadas ("selective comparison").

c) El contexto, comprendido como su habilidad para entender un ambiente en particular ${ }^{96}$. A este respecto, también se distinguen los siguientes aspectos:

i) La evolución de la capacidad del menor. Dicha evolución de acuerdo a Erikson, comprendería, a lo menos, ocho etapas ${ }^{97}$.

ii) En virtud de lo anterior existe una capacidad para cambiar.

iii) La actuación del menor ante el mundo va a depender de la percepción que tenga de éste ${ }^{98}$.

\section{Cómo deben apreciarse las condiciones de madurez}

A las "condiciones de madurez" se les puede dar un alcance general, en cuyo caso existirían unas condiciones de madurez generales que habilitarían a la celebración de cualquier acto, o un alcance específico, con relación al acto que se celebra. A pesar de que la doctrina no ha tratado esta distinción, ningún autor ha planteado que las condiciones de madurez puedan ser consideradas de forma general. Tal vez, la explicación de ello se debe a la propia naturaleza de las condiciones de madurez, que variarán de acuerdo al acto de que se trate. Este por lo demás es el más antiguo y tradicional de los criterios seguidos por el Derecho. De tal manera, si se analiza la capacidad o aptitud para ser imputable, ésta es diferente según las reglas de la responsabilidad penal, civil contractual o extracontractual. También desde esta perspectiva, el legislador

\footnotetext{
${ }^{96}$ Garbarino, "The Child's", cit. nota n. 57, p. 22.

${ }^{97}$ Garbarino, "The Child's", cit. nota n. 57, p. 24.

${ }^{98}$ A pesar que Garbarino se preocupa de todos estos aspectos con profundidad, para los efectos de este trabajo sólo mencionaré los aspectos precedentemente indicados. Garbarino, "The Child's", cit. nota n. 57, pp. 19-32.
} 
tradicionalmente exige una edad menor para ser imputable. Lo anterior se debe a que en esta materia se requiere que el menor tenga el más elemental de los conocimientos: el del bien y del mal. En cambio, en materia de capacidad patrimonial-contractual no basta tener un elemental conocimiento del bien y el mal para ser capaz, sino que se debe dominar conceptos como costo de oportunidad, precio de mercado, riesgos, etcétera. Así, el criterio de las condiciones de madurez del menor varía de acuerdo a la materia sobre la que recae. En tal sentido, se explica cómo las condiciones de madurez que rodean al menor deben ser tomadas en consideración al momento de determinar su madurez. En los casos de menores vulnerables, el desamparo gravitará en las condiciones de madurez, aunque no se puede llegar al extremo de considerar a estos menores como menores de segunda clase ${ }^{99}$. Por ello, para determinar la capacidad del menor se debe atender a las normas específicas que le son aplicables y a la naturaleza concreta del acto de que se trate.

\section{Algunas CONCLUSIONES}

Una parte importante de la doctrina en el Derecho comparado critica tanto la expresión "condiciones de madurez" como también "interés superior del niño" por encontrarlos conceptos vagos y poco concretos. A pesar de esta crítica, el interés superior del niño se ha venido abriendo paso fuertemente en el Derecho chileno y comparado, determinado lo que se ha denominado como el Moderno Derecho de la Infancia y de la Adolescencia. Sin embargo, no existen trabajos que se centren en las condiciones de madurez como criterio determinante de la capacidad extrapatrimonial de los niños y especialmente de los adolescentes. Ello se contrapone con la importancia que se le ha asignado a este término en el Derecho comparado, que ha comenzado a reconocer a las condiciones de madurez como un criterio indispensable para determinar la capacidad, y en nuestra legislación, que continuamente recurre a él.

En resumen, los argumentos a favor de las condiciones de madurez como criterio fundamental para considerar la capacidad extrapatrimonial del menor son los siguientes:

\footnotetext{
${ }^{99}$ Así, por ejemplo, puedo citar el artículo 8 de la Ley de la Generalidad Valenciana de fecha 5 de diciembre de 1994, № 7/1994, que establece textualmente lo siguiente:

"Artículo 8. La infancia.

Los niños y niñas, en cuanto sus condiciones de madurez lo permitan, deberán participar activamente en las actividades que se realicen en su núcleo primario de convivencia y en todo aquello que le concierna, procurándose su plena integración en la vida familiar y social".

Este es un criterio bastante restringido respecto de las condiciones de madurez del menor. Así, el menor desamparado en lugar a tomar sus propias decisiones, "en la medida que sus condiciones de madurez se lo permitan", tiene sólo derecho a "participar activamente en las actividades de su núcleo primario de convivencia". De esta forma pareciera ser que los menores, en situaciones de desamparo, tienen un ámbito de capacidad menor que los menores que están con sus padres.
} 
a) El establecimiento de las condiciones de madurez como condición determinante de la capacidad del niño y adolescente se acerca a la tradición jurídica española y francesa en esta materia. Esto se debe a que el Derecho Civil español -al igual que el Derecho francés- se apartó del Derecho romano al no distinguir entre infante, impúber y menor adulto ${ }^{100}$. Entonces, el establecer un límite objetivo absoluto (que no sería otro que el de la edad) se aleja de la tendencia seguida por la mayoría de los Derechos Civiles latinos modernos.

b) Sin perjuicio de lo anterior, la edad sigue siendo un criterio relevante en materia de capacidad, por lo que-reconociendo la tendencia de Bello a rescatar la edad como un criterio determinante de la capacidad- se ha distinguido entre niño y adolescente. Lo que nos conduce a sostener que, por regla general, los adolescentes son capaces en materia de capacidad extrapatrimonial y los niños por regla general son incapaces. Ello se sustenta tanto en el artículo $16.3^{\circ}$ de la $L T F$, como en los demás argumentos expuestos en el presente trabajo.

c) Como la edad es un criterio arbitrario ${ }^{101}$, se ha adoptado como criterio corrector "las condiciones de madurez". Esta posición es la que mejor se adapta a las posturas generalmente aceptadas por el Derecho Internacional y por Derecho comparado y es totalmente sustentable en Chile.

\section{BibliOgRAFÍA CITADA}

Albaladejo García, Manuel, Derecho Civil I: Introducción y Parte General, volumen I, Bosch Editor, S.A., Barcelona, 1996.

Armenteros Chaparro, Juan Carlos, Objeción de Conciencia a los Tratamientos Médicos. La Cuestión de la Patria Potestad, Editorial Colex, Madrid, España, 1997.

\footnotetext{
${ }^{100}$ La diferencia fundamental en esta materia radica en el concepto de simplemente impúber, que es aquel que no tiene la aptitud para procrear, y menor adulto, que es aquel que no siendo impúber, aún no es mayor de edad. Los infantes pertenecen a una categoría especial, en cuanto se les considera incapaces absolutos o inimputables y no relativos, como a los menores adultos. Estas distinciones han pervivido en la mayoría de los códigos de Latinoamérica, como los códigos Civiles argentino, colombiano, chileno y venezolano.

${ }^{101}$ El fijar un límite de edad para adquirir la capacidad es arbitrario, ya que ipor qué una persona ha de estar incapacitado para realizar un acto un día y el mismo individuo al día siguiente (vencimiento del plazo) ha de ser considerando capaz? En otras palabras, la arbitrariedad en esta posición consiste en no tomar en cuenta las causas que generan la incapacidad, o sea la aptitud del menor conforme a su nivel de madurez. Por otra parte, la pretensión de fijar un canon de edad general se va desvaneciendo, si se consideran normativas específicas del Derecho Internacional con relación a la infancia y adolescencia. Así, se discute si dicho límite sería la edad de dieciséis o dieciocho años. En el Convenio Europeo de Luxemburgo sobre Reconocimiento y Ejecución de Decisiones en Materia de Custodia de Menores de 20 de mayo de 1980, se considera como menor al individuo que tiene menos de dieciséis años de edad, cualquier que sea su nacionalidad y siempre que no tenga derecho a fijar su residencia. Muy similar es el convenio Marroquí-Hispano de 30 de mayo de 1997, que fija como límite la edad de dieciséis años.
} 
Atienza, Manuel y Ruiz, Juan, Ilícitos Atípicos, Editorial Trotta, 2000.

Barcia Lehmann, Rodrigo, "Recensión llícitos Atípicos", de Atienza, Manuel y Ruiz, Juan, Revista lus et Praxis, 7, 2, 2001, pp. 493-496.

"Informe en Derecho sobre la capacidad de los menores para recibir la denominada píldora del día después", en Revista de Chilena de Derecho Privado, 7, 2006, pp. 137-158.

"Fallos y comentario a los fallos de la Corte de apelaciones de Santiago y Corte Suprema sobre recurso de protección, interpuesto por la distribución de laboratorios de la denominada píldora del día después a adolescentes (menores mayores de catorce años)", Revista lus et Praxis, 13, 2007, pp. 409-422.

Barcia Lehmann, Rodrigo y Méndez Royo, Daniela, "El Principio del Ejercicio Progresivo de los Derechos de la Infancia y Adolescencia desde la Perspectiva de dos Sentencias Paradigmáticas en el Derecho Inglés de la Familia", Revista Chilena de Derecho de Familia, 1, 2010, pp. 117-136.

Barcia Lehmann, Rodrigo y Riveros Ferrada, Carolina, "El Derecho al Conocimiento del Origen Biológico como un Derecho Fundamental de Naturaleza Civil-Constitucional Derivado del Derecho a la Identidad y de la Dignidad Humana", en GÓmez De LA TORRE (directora), Las Técnicas de Reproducción Humana Asistida. Desafíos del Siglo XXI: Una mirada Transdisciplinaria, AbeledoPerrot, LegalPublishing Chile y Thomson Reuters, Escuela de Posgrado, U. de Chile, Santiago, Chile, 2013, pp. 189-221.

Bo Jané, M. y Caballero, R., "El Nuevo Derecho del Menor a ser Oído: ¿Sujeto Activo en la Determinación de sus Intereses?", Revista Jurídica Española La Ley, 1.996-6, La Ley, Actualidad Civil.

Castán VÁsquez, José María, "Título VI del Libro I del CCE", en Albaladejo, Manuel, (editor), Comentarios al Código Civil y Compilaciones Forales, tomo. III, volumen. 2, Editorial Revista de Derecho Privado, Madrid, 1982.

Cillero Bruñol, Miguel, "Infancia, autonomía y derechos: una cuestión de principios", en Boletín del Instituto Interamericano del Niño, № 234, (también disponible en: www.iin.oea.org/Infancia_autonomia_derechos.pdf [visitado el 13/03/2013] p. 5).

"El Interés Superior del Niño en el Marco de la Convención Internacional sobre los Derechos del Niño", en Justicia y Derechos del Niño, № 9, UNICEF, Santiago de Chile, 2007, pp. 125-142.

D'Antonio, Daniel, Derecho de Menores, $3^{\mathrm{a}}$ edición, Buenos Aires, Editorial Astrea, 1986.

D'ORS, Álvaro, Derecho Privado Romano, Ediciones Universidad de Navarra, S. A., Pamplona, 1991. 
De Castro y Bravo, Federico, Derecho Civil de España, tomo. II. Derecho de la Persona. Parte Primera. La Persona y su Estado Civil, Madrid, España, Instituto de Estudios Políticos, 1952.

Díez PICAzo, Luis, "Capacidad civil y capacidad penal", en Ruiz-Gallardón, Isabel y García De Pablos, Antonio (editores), Los menores ante el Derecho, Servicio de Publicaciones Facultad de Derecho, UCM, Jaén, España, 2005.

Diges JunCo, M. A. y QueCuty, M. L., "El Psicólogo Forense Experimental y la Evaluación de Credibilidad de las Declaraciones en los Casos de Abuso Sexual a Menores", Revista del Poder Judicial, 35, 1994.

Garbarino, James, Chapter II, Children's Rights in America: "The Child's Evolving Capacities (Articles 5 and 14 United Nations Convention on the Rights of the Children's)", en: Price Cohen, Cynthia y Davidson, Howard A. (editors), U. N. Convention on the Rights of the Child Compared with United States Law, American Bar Association, 1990.

Gete-Alonso, María del Carmen, Gil Rodríguez, Jacinto, Hualde Sánchez, José Javier y Puig FerRIOL, Luis, Manual de Derecho Civil I (Introducción y Derecho de la Persona), Marcial Pons, Madrid, 1995.

Guzmán Brito, Alejandro, "La Historia Dogmática de las Normas sobre Interpretación", en Conferencias y Ponencias Presentadas en el Congreso sobre Interpretación, Integración y Razonamiento Jurídicos, Editorial Jurídica, Santiago, Chile, 1992.

Herce de la Prada, Vicente, El Derecho a la Propia Imagen y su Incidencia en los Medios de Difusión, Bosch editorial, Barcelona, 1994.

Herrera, Marisa, "La democratización de las relaciones de familia. Desafíos de la relación padres e hijos desde el principio de capacidad progresiva de niños, niñas y adolescentes", en Gómez de la Torre Vargas, Maricruz (Directora), Revista del magíster y doctorado en derecho, №4 / 2011, Facultad de Derecho Universidad de Chile, Escuela de Posgrado, pp. 17-56 (también disponible en: http://www.revistas.uchile.cl/index.php/RMDD/ article/viewFile/18707/28603 [visitado el 12/03/2013]).

Herrán Ortiz, Ana Isabel, "Nueva perspectiva de la protección jurídica del menor. La experiencia legislativa española", en Lledó YAGüE, Francisco, Sánchez SÁnchez, Alicia (directores), Monje Balmaseda, Óscar (coord.), Los 25 temas más frecuentes en la vida práctica del derecho de familia, Tomo I. Parte Sustantiva, Dykinson S.L., 2011.

IglesiAs-Redondo, Juan, Derecho Romano, Ariel Derecho, Barcelona, 1999, p. 93; Schulz, Fritz, Derecho Romano Clásico, Bosch, Barcelona, 1960.

Lete del Río, J. M., Derecho de la Persona, 2a edición, Tecnos, Madrid, 1986.

Linacero De La Fuente, María, "La protección del menor en el Derecho Civil español. Comentario a la Ley Orgánica 1/96, de 15 de enero", Actualidad Civil, 48, 1999. 
, Protección jurídica del menor, Editorial Montecorvo S.A., Madrid, España, 2001.

Lovera Parmo, Domingo A., "Niño, adolescente y derechos constitucionales: de la protección a la autonomía", en Cillero, Miguel (director), Justicia y Derechos del Niño, número 11, UNICEF, pp. 11-54 (también disponible en: http://www.unicef.org/argentina/spanish/Justicia_y_Derechos_11_web. pdf [visitado el 13/03/2013]).

Moreno Trujillo, Eulalia, Actuaciones de Protección del Menor: El Menor en la Legislación Actual, editorial Trigraphis, Granada, España, 1997.

NuÑEz MuÑIz, Carmen, "Algunas Consideraciones sobre la Ley Orgánica 1/1996 de 15 de Enero, de Protección Jurídica del Menor", La Ley, Diario No 4.135, de 2 de octubre de 1996.

Quintana Bravo, Fernando, Interpretación y Argumentación Jurídica, Editorial Jurídica, Santiago, Chile 2006.

Ramos Chaparro, Enrique, "Enfermedad Física, Autogobierno e Incapacitación", Poder Judicial, 34, 1994.

, "Niños y jóvenes en el Derecho civil constitucional", Revista Derecho Privado y Constitución, 3, 7, 1995.

Ramos Pazos, René, Derecho de Familia, tomo II, $7^{\text {a }}$ edición actualizada, Editorial Jurídica, Santiago, Chile, 2007.

Rivera Restrepo, José Maximiliano, "La Patria Potestad y los Derechos Fundamentales", Revista Chilena de Derecho de Familia, 2, 2011 (en proceso de publicación).

Rivero Hernández, Francisco, El Interés del Menor, Madrid, Dikinson, 2000.

RIverOs FerRADA, Carolina, "El rol protector del Estado para con las niñas y los niños frente al derecho de los padres para criarlos y educarlos", Revista Chilena de Derecho de Familia, Ruz LÁrTIGA, Gonzalo (Director científico), AbeledoPerrot, LegalPublishing Chile, III, Santiago de Chile, 2010, pp. 123-138.

Rojas Miño, Irene, Manual de Derecho del Trabajo, LexisNexis, Santiago de Chile, 2004.

Royo JARA, José, La Protección del Derecho a la Propia Imagen, Madrid, Colex, 1987.

Varas Braun, Juan Andrés, "Decisiones vitales y representación parental: Fundamento y límites", en Estudios Derecho Civil V, Jornadas Nacionales de Derecho Civil, Concepción, AbeledoPerrot, LegalPublishing, Santiago de Chile, 2009, pp. 335-356.

Verhellen, E., Convention on the Rights of the Child; Background, Motivation, Strategies, Main Themes, Garant, Verhellen and Garant Publishers N. V., 1994, Belgium. 
Zarraluqui, "El tratamiento de los menores y los jóvenes", en Comentarios vLex (30 de septiembre de 2009). En: http://prensa.vlex.es/vid/zarraluquieznarriaga-abogados-67460961 [visitado el 16/03/2013]. 